5

14. GS:

C55s CIR 558

Geol Suney

c. 1

\title{
Distribution of Boghead Algae in Illinois Basin Coal Beds
}

Russel A. Peppers and Richard D. Harvey

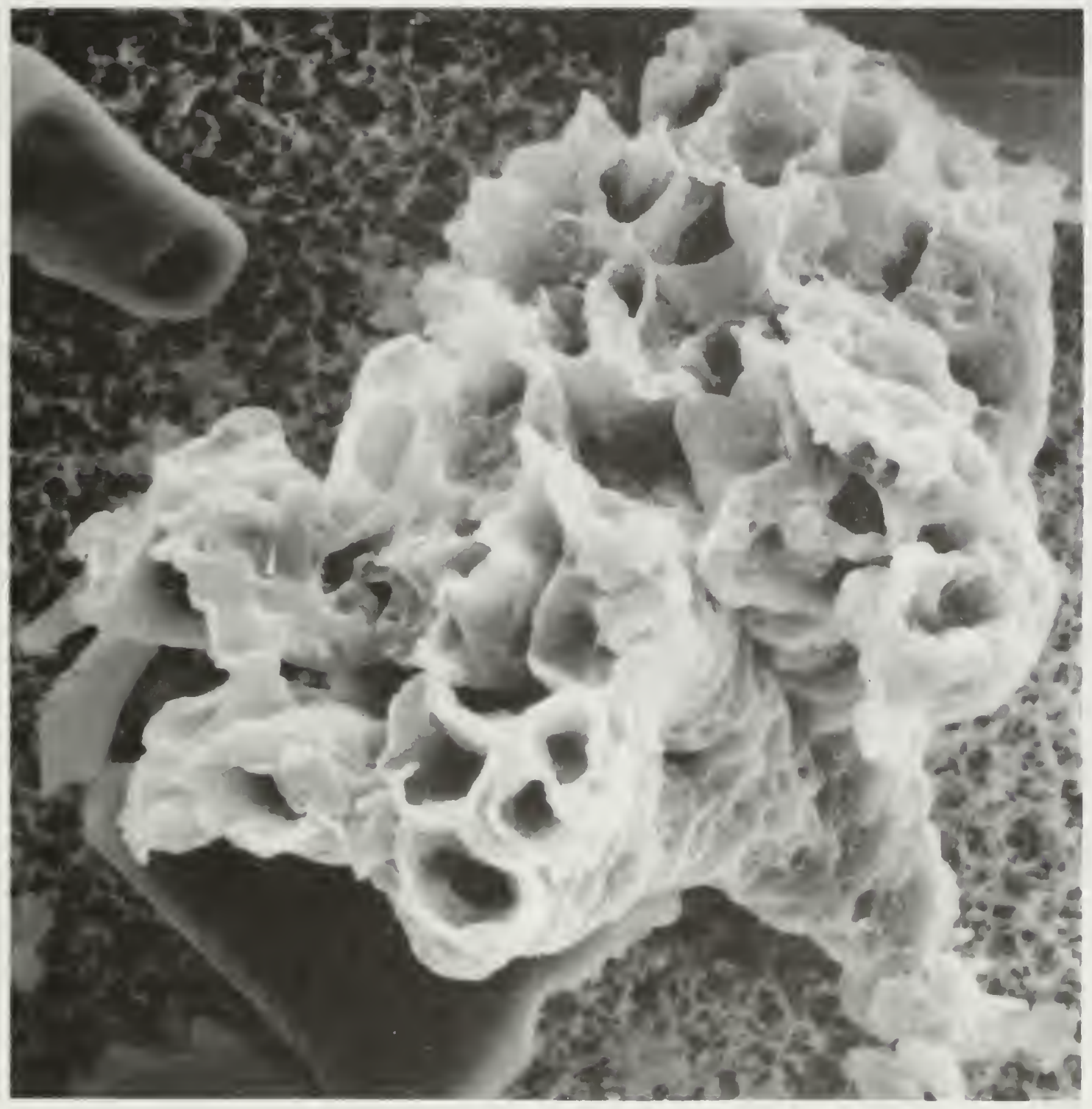

Circular 5581997

Department of Natural Resources

ILLINOIS STATE GEOLOGICAL SURVEY 


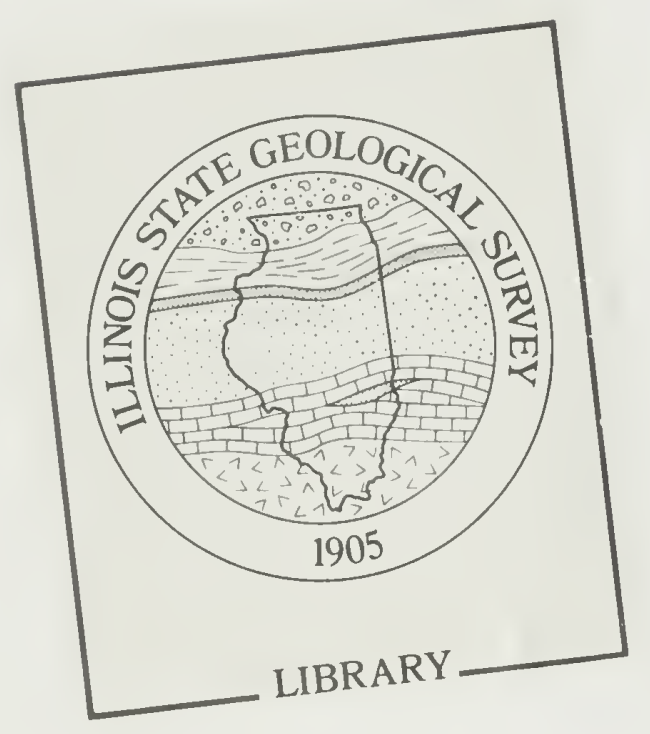




\section{Distribution of Boghead Algae in Illinois Basin Coal Beds}

Russel A. Peppers and Richard D. Harvey

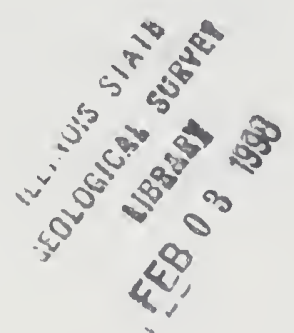

Circular $558 \quad 1997$

ILLINOIS STATE GEOLOGICAL SURVEY

William W. Shilts, Chief

Natural Resources Building

615 E. Peabody Drive

Champaign, Illinois 61820-6964

(217) $333-4747$ 



\title{
FOREWORD
}

\author{
from the Chief
}

Not until 1951 did Robert Kosanke of the Illinois State Geological Survey discover fossils of the Botryococcus alga in several Illinois coals, even though for a half century fossil algae had been reported in coals worldwide.

In 1963, Dr. Russel Peppers arrived at the Geological Survey and began his career-long study of the fossil pollens and spores in coal. In his studies of thousands of coal samples, Peppers kept Kosanke's discovery in mind and began collecting samples that contained this particular alga. At last count, he had 43 samples of coal from widespread coal seams in Illinois, Indiana, and Kentucky.

In this report, Peppers and his colleague Dr. Richard Harvey, an expert in the description and classification of coals and coal macerals, summarize their investigation into the fossil algae in these 43 coal samples. Peppers and Harvey found that the alga occurs in 12 Illinois coal beds. Their data on the distribution of Botryococcus in coal may help geologists identify, correlate, and map coal seams across the Illinois Basin.

The presence of the alga in a coal or shale can tell us about the changing environments of the ancient swamps that covered Illinois about 315 to 310 million years ago. Peppers and Harvey compared the distribution of Botryococcus with that of the spore assemblages in their samples; they found that the alga is most abundant in layers in which Lycospora are most abundant. Botroyococcus lived in freshwater, and this association reinforces previous evidence that lycopod trees grew in wet and periodically flooded swamps.

Peppers and Harvey also found the alga in layers of shale that originated as mud in freshwater swamps. Where seawater covered the swamps and decomposing plants, there is likely to be high-sulfur coal. Because freshwater shales commonly lie directly over low-sulfur coal, finding shales with significant amounts of the Botryococcus alga may help geologists locate deposits of low-sulfur coal.

As with most research, this study raises new questions just as it is answering the ones the scientists began with. The alga Botryococcus is still living today unchanged for over 400 million years. But it is not found in any Illinois coal beds above the lower Middle Pennsylvanian (about 310 million years ago), even though it is found in coals from other locations. Why the disappearance? And even though the fossil algae were buried in coals thousands of feet deep for millions of years, the cell bodies weren't flattened or coalified. Why not? These are indeed intriguing questions for further investigation.

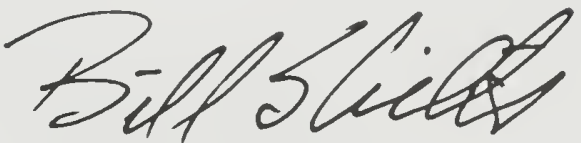

William W. Shilts, Chief Illinois State Geological Survey 


\section{ACKNOWLEDGMENTS}

We thank Donald Lowry (ISGS), who prepared the SEM photographs, and Curtis Klug (University of Iowa) and Donald Mikulic and Beverly Herzog (ISGS), who reviewed the manuscript and provided useful suggestions.

\section{Editoral Board}

Jonathan H. Goodwin, Chair

Michael L. Barnhardt

Heinz H. Damberger

Anne L. Erdmann

Beverly L. Herzog
David R. Larson

Donald G. Mikulic

William R. Roy

C. Pius Weibel

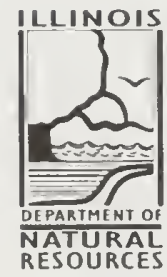

Printed by Authority of the State of Illinois/1997/800 printed with soybean ink on recycled paper 


\section{CONTENTS}

\section{ACKNOWLEDGMENTS}

ABSTRACT

INTRODUCTION

Morphology and Ecology of Botryococcus

COAL BEDS THAT CONTAIN BOTRYOCOCCUS

Reynoldsburg Coal Bed (Illinois)

Breckinridge and Bell Coal Beds (Kentucky), Bell Coal Bed (Illinois), and St. Meinrad Coal Member (Indiana)

Unnamed Coal Bed (Illinois)

Mariah Hill Coal Member (Indiana) and Dunbar Coal Bed (Kentucky)

Tarter Coal Member (Illinois) and Lower Block Coal Member (Indiana)

Hermon Coal Member (Illinois)

Brush Coal Member (Illinois)

Buffaloville Coal Member (Indiana) and Lewisport Coal Bed (Kentucky)

Bancroft(?) Coal Bed (Kentucky)

Delwood Coal Bed (Illinois) and Equivalent Coal in Kentucky

New Burnside Coal Bed (Illinois)

Unnamed Coal (Indiana) Equivalent to the Murphysboro Coal Member (Illinois)

ALGAL AND SPORE ABUNDANCE IN THE LEWISPORT COAL BED AND

OVERLYING AND UNDERLYING STRATA IN UNION COUNTY, KENTUCKY

\section{TABLES}

1 Location of coal beds containing Botryococcus

2 Palynology of selected coal samples in which Botryococcus is common or abundant

3 Maceral analysis of selected samples

\section{FIGURES}

1 Cross sections of modern Botryococcus

2 Location of coal beds containing Botryococcus

3 Stratigraphic and geographic occurrences of Botryococcus in the Illinois Basin

4 Relative abundance of spores in the Lewisport coal and overlying and underlying strata at sample site 35 in Union County, Kentucky

5 Relative abundance of spore taxa in representative coal beds in which Botryococcus is abundant or common

6 SEM micrographs of Botryococcus show the open structure of the cups in the organisms

PLATE

1 The occurrence of Botryococcus in crushed particles of coal 
Digitized by the Internet Archive in 2012 with funding from

University of Illinois Urbana-Champaign 


\section{ABSTRACT}

The alga Botryococcus was observed in coal macerations from twelve coal beds in the Tradewater Formation (Lower and lower Middle Pennsylvanian) in the Illinois Basin. In Illinois, Botryococcus occurs in the Bell, Delwood, Lewisport, New Burnside, and Reynoldsburg Coal Beds, in the Brush, Hermon, Murphysboro, and Tarter Coal Members, and in an unnamed coal bed; in Indiana it occurs in the St. Meinrad, Lower Block, and Buffaloville Coal Members and an unnamed coal bed; and in Kentucky it occurs in the Bancroft(?), Bell, Breckinridge, Lewisport, and Delwood coal beds. Some names identify the same coal, whose designation may vary by state.

Although Botryococcus is rare at most of the 43 sample sites where it was found, it is abundant at two sites in the Lewisport and at one site each in the Reynoldsburg, New Burnside, Delwood, and Brush Coals and Breckinridge coal bed. It is common at two sites in the Delwood and one site in the Tarter and Mariah Hill Coals. Botryococcus has been found more commonly (14 sites) in the Delwood than in any other coal. A distribution pattern of Botryococcus abundance is not apparent because of the small number of sites of each of the coals containing the alga. Although Botryococcus is still a living genus, it has not been observed in coals in the Illinois Basin above the lower Middle Pennsylvanian, even though hundreds of samples of the most extensive coal seams in the basin, which occur in the upper Middle Pennsylvanian, have been examined.

The Lewisport coal and overlying and underlying strata at one sample site were macerated to compare the abundance of Botryococcus with the lithology and composition of the spore assemblages. The alga is most abundant in the coal and overlying coaly shale in which Lycospora, produced by large lycopod trees, is most abundant. Botryococcus is least abundant in the under- clay and gray shale that overlies the coaly shale in which fern spores are most abundant; Granasporites medius, representing the arborescent lycopods Diaphorodendron and Synchysidendron, is most abundant in the gray shale. Sphenopsid spores are abundant in the coal, underclay, and some intervals of gray shale overlying the coal. As with the Lewisport, coal beds in which Botryococcus is abundant also contain an abundance of Lycospora.

Petrographic analyses of selected samples indicate an average of 0.5 to 3.2 volume percent of Botryococcus in coals bearing this type of alginite (liptinite group of macerals). The Botryococcus occurs in irregularly shaped colonies. These colonies are embedded in a matrix of desmocollinite vitrinite along with small sporinite (Lycospora) and to a lesser extent other macerals that are common in coals of bituminous rank. Up to $60 \%$ or more of some ultra-thin coal layers consists of algae colonies. Such layers or bands are properly termed torbanite. Microscopical (optical and scanning electron microscope) studies suggest that the colonies of Botryococcus have not been permanently compressed from their original morphology during subsequent coalification.

Because Botryococcus lived in fresh to brackish water, the association of abundant algae and Lycospora reinforces evidence from earlier paleobotanical studies that coal swamp lycopod trees grew in the parts of the swamps that were very wet and periodically flooded.

A knowledge of the distribution of abundant Botryococcus may aid in outlining lower-sulfur content areas within coal beds. High-sulfur coal is more closely associated with coal swamps that were near shore and drowned by marine water than with swamps that were higher on the delta plain and drowned by freshwater stream deposits.

\section{INTRODUCTION}

Algae in coal in the Illinois Basin were first reported by Kosanke in 1951. He compared the fossil algae in the top several inches of the Tarter Coal Member from an outcrop in Fulton County with the living alga Botryococcus. We have subsequently observed Botryococcus in several other coal beds in the Illinois Basin during routine palynological analyses. In most samples, algae are rare, but in several samples they are abundant.

One of the purposes of this study was to identify the extent and stratigraphic occurrence of the coals that contain Botryococcus and to determine whether there is a pattern in the distribution and abundance of the alga. A related goal was to determine whether the alga's presence could be used in biostratigraphic correlations. The study also sought to provide clues concerning the environments of deposition of the coals, which could aid in identifying coal with relatively low sulfur content. Finally, we wanted to determine the alga's distri- bution in coal and to characterize its morphology in coal after compaction.

Palynology of the Lewisport coal and overlying and underlying strata in an outcrop in Union County, Kentucky, was studied in detail to determine the relation of spore abundance to Botryococcus abundance. This relationship clarifies the paleoecology of ancient Pennsylvanian peat swamp plants because the ecology of living Botryococcus is known. In addition, spore analysis of several coal samples of different ages that contain abundant Botryococcus indicates the kinds of vascular plants most common in the coal swamps that supported the growth of algae.

Petrographic analyses of several coal samples containing abundant Botryococcus were made, including a scanning electron microscope (SEM) study that characterized Botryococcus morphology. Petrography also revealed the relative abundance and relationship of 
Botryococcus to macerals in several unmacerated coal samples. The scope of the petrographic study did not include analysis of all coals containing Botryococcus nor the particular parts of the beds that contain the alga. Thus, we cannot determine which layers within the coal beds would be classified as boghead coal.

The composition and origin of boghead coals and related torbanites have been discussed in detail by Thiessen (1925), Blackburn and Temperley (1936), and Allen et al. (1980). These publications summarized the nomenclature of algal coals and shales and the history of the investigations. Boghead coal, bituminous shale, cannel coal, torbanite (black oil shale), and other rocks containing algae have not been satisfactorily classified. Schopf (1949) noted that boghead coal, which is nonbanded, is composed mainly of algae but often contains some spores. Cannel coal, which is also nonbanded, mainly contains spores but may also contain algae. Occasional colonies of Botryococcus may also be present in attrital portions of banded coals.

\section{Morphology and Ecology of Botryococcus}

Modern Botryococcus is planktonic and widely distributed in temperate and tropical climatic zones throughout the world. It occurs in permanent to semipermanent freshwater pools and lakes, but occasionally it grows in salt water. Some species live in still water, and others live in moving water. Botryococcus has also been found in peat (Blackburn and Temperley 1936). The presence of starch in living Botryococcus places it among the green algae (Chlorophyceae), but the structure of cell walls and color of the plastids are characteristic of yellow-green algae. Cells produce large amounts of oil.

Modern Botryococcus forms free-floating, amorphous colonies enclosed in a cartilaginous green or orange, wrinkled and folded envelope. The closely spaced, ovoid or cunate cells usually occur in groups of multiples of two in a single layer toward the edge of the colony (fig. 1). The cell groups are radially arranged and connected by broad, delicate strands.

Cell walls are transversely divided into two unequal overlapping parts, with the lower part being longer. A cell is enclosed within a waxy thimble, which itself is partly enclosed within a fatty cup that has a stalk-like projection into the center of the colony (fig. 1). Cells reproduce by longitudinal division. The resulting cells produce new thimbles and cups within the old ones; the lower part of the cell forms the new cup.

After the algae die, the cells usually decompose, but the waxy-fatty skeletons of the colony are usually preserved. Fossil Botryococcus consist of the skeletons as modified by sedimentation and coalification (Traverse 1955, Smith 1950).

Bertrand and Renault $(1892,1893)$ collaborated for over 20 years in studying algal coals and shales. Renault (1899-1900) concluded that boghead coals were formed in swamps, lakes, and pools as an organic jell that had been altered by microorganisms. Spores, cuticles, plant cells, and debris were suspended in the jell. However, Bertrand and Renault's explanation was not widely accepted because they proposed that bitumen from another source infiltrated the matrix and did not specify an alga that matched the characteristics of boghead algae. Jeffrey (1910) suggested that the algae are spores.

Zalessky (1914) described the rubbery oil deposits produced by Botryococcus braunii in shallow parts of a present-day lake in Turkistan. The algal colonies in the oil mass, as seen in thin sections, resemble the colonies of algae in boghead coals. Zalessky (1926) also identified $B$. braunii in balkhashite, the sapropelic rock of Russia. Thiessen (1925) described living algae in salt lakes and lagoons in South Australia and showed that they are closely related or identical to the algae in boghead coals. He stated they resembled blue-green algae in some respects but was not certain of their affinity. He proposed the name Elaeophyton for what are actually colonies of Botryococcus. Blackburn and Temperley (1936) described in detail the algae from boghead coals and showed that the fossil forms of boghead algae are closely related to modern $B$. braunii. Niklas and Phillips (1974) and Niklas (1976) correlated fossil boghead algae and living Botryococcus by comparing microchemical compositions and morphologies.

Dulhunty (1944) studied a Permian torbanite in New South Wales and proposed that deposits of Botryococcus do not form in peat swamps that contain abundant humic matter. He suggested the water, which contained dissolved humic and mineral matter, flowed from swamps and marshes into lakes. No vegetation, except for algae, was established in the lakes because the water level frequently fluctuated. Moore (1968) believed that algae probably lived toward the center of lakes where sufficient oxygen was available because organic matter would be most abundant around the margins of the lakes. The association of Botryococcus with opaque attritus in coal led Schopf (1952) to conclude that the attritus had formed under moist rather than dry conditions, as previously presumed.

Since the vitrinite in the boghead coal at the top of the Tarter Coal Member occurs in very thin bands, Kosanke (1951) concluded that the freshwater peat bog did not support many arborescent plants. He suggested, however, that the upper part of the Tarter Coal might not be a true boghead because of the large percentage $(24 \%)$ of vitrinite. He macerated some of the coal, but isolated individual colonies showed little structure.

Bradley (1966) described the sediment in Mud Lake, Florida, a modern analog to oil shale. The sediment contains a layer of ooze made up of abundant Botryococcus that slowly accumulates about 3 feet below the water-mud contact of the shallow lake. Fecal pellets containing remains of algae are common in the ooze, and plant debris is rare. At greater depths, after having depleted the available nutrients from the mud, the algae produce oil, fats, and pigments.

Dulhunty (1944, p. 32) remarked that "the very primitive nature of the living Botryococcus suggests that the organism has not changed for a very long time, and justifies the belief that it has descended from the late 


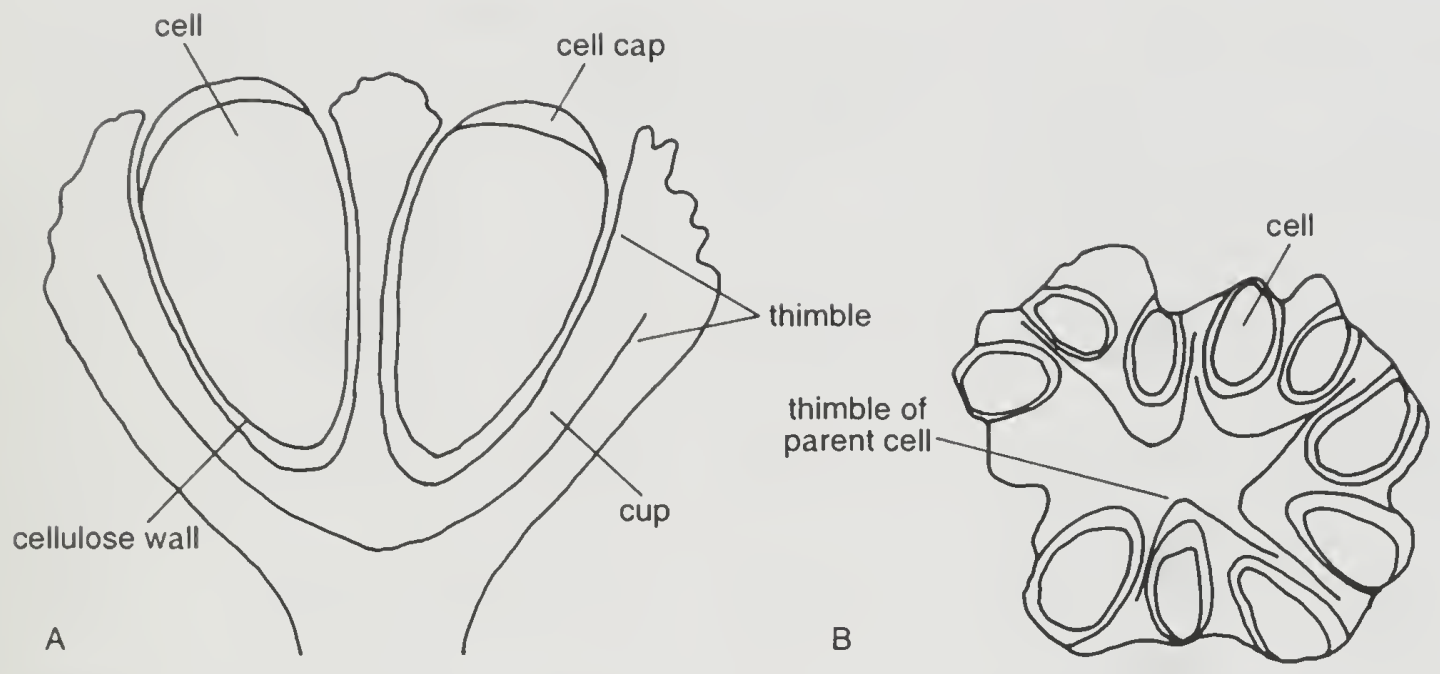

Figure 1 A. Cross section of a pair of modern cells of Botryococcus braunii Kützing. B. Colony of $B$. braunii. Cells, cell caps, and cell walls are not present in fossil Botryococcus (adapted from Blackburn and Temperley 1936).

Paleozoic algae preserved in torbanite without appreciable modification." White's description (in Bain 1906) of algae in the Galena Formation of Illinois strongly suggests that Botryococcus can be traced back at least to the Ordovician.

\section{COAL BEDS THAT CONTAIN BOTRYOCOCCUS}

Coals containing Botryococcus are widely distributed in the Illinois Basin (table 1 and fig. 2). Analyses of the samples are discussed below according to stratigraphic unit, oldest to youngest (fig. 3). References in the text are to the unit name in southern Illinois. Correlation with equivalent (but occasionally differently named) units elsewhere in the basin are given in figure 3.

\section{Reynoldsburg Coal Bed (Illinois)}

Kosanke (1950) studied the palynology of the Reynoldsburg Coal Bed near the town of Reynoldsburg, Johnson County; and Smith (1957) reported on strippable reserves of the coal in southern Illinois. Trask and Jacobson (1990) mapped the coal outcrop near Reynoldsburg. The coal lies just above the Pounds Sandstone Member and at the base of the Tradewater Formation (formerly Abbott Formation; Greb et al. 1992). It is late Morrowan in age (fig. 3). In places the canneloid and bituminous coal grades upward into an oil shale several feet thick, called the Ozark oil shale, that was locally used in cookstoves and fireplaces. At site 28 (table 1), the Reynoldsburg contains abundant Botryococcus and opaque, finely divided kerogen. Spores in maceration 2695 are poorly preserved, but the assemblage is dominated by Densosporites, which were produced by small lycopods.

Botryococcus is rare in the coaly shale at site 29, about 2 miles east of Reynoldsburg, and in the coal at site 31, about 11 miles east of Reynoldsburg. The canneloid coal and bituminous shale at site 29 were used by Barrett (1922) for experimental distillation of the deposits as a possible source of oil. About 6,000 cubic feet of gas and 36.6 to 45.1 gallons of crude tar per ton of coal shale were distilled. At sample site 31, Laevigatosporites (38\%) and Densosporites ( $25 \%$ ) dominate, and only $24 \%$ of the spore assemblage is made up of Lycospora.

\section{Breckinridge and Bell Coal Beds (Kentucky), Bell Coal Bed (Illinois), and St. Meinrad Coal Member (Indiana)}

Hower et al. (1986) described the petrology and geochemistry of the Breckinridge coal bed in Hancock County, Kentucky. Botryococcus braunii is very abundant in the seam, which they considered a torbanite. Botryococcus is also abundant in a sample of the Breckinridge coal examined from site 42 in Breckinridge County, $8 \mathrm{~km}$ south of Cloverport. Hower et al. (1986) stated that the seam is Morrowan (Westphalian A) in age. The spores are not sufficiently well preserved to permit a percentage count; the presence of Renisporites confossus and Endosporites globiformis and the lack of Schulzospora rara, however, indicate that the coal is early Atokan (early Westphalian B) in age and probably correlates with the Bell coal bed (fig. 3 ).

At sites 26 and 27 in Johnson County, Illinois, the Bell Coal Bed, which is stratigraphically about $12.2 \mathrm{~m}$ above the Reynoldsburg Coal, contains rare specimens of Botryococcus. Maceration 2611 is from coal fragments collected around an old mine entrance, and maceration 3059 is from an abandoned strip mine. A total of $95 \%$ and $74 \%$ of the spore assemblages in macerations 2611 and 3059, respectively, are Lycospora. Cristatisporites indignabundus and Densosporites annulatus, which were 


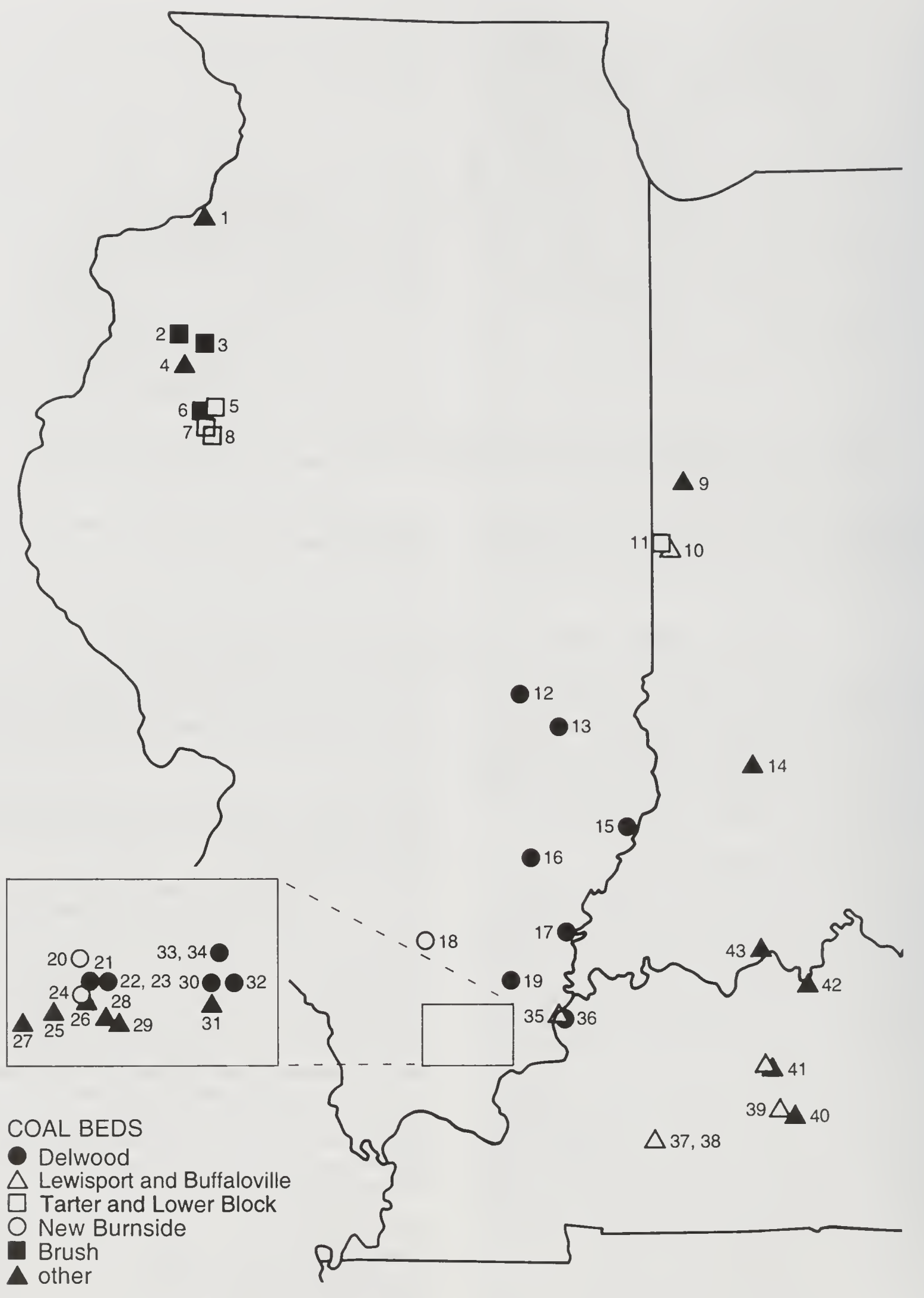

Figure 2 Location of coal beds containing Botryococcus. 
Table 1 Location of coal beds containing Botryococcus.

\begin{tabular}{|c|c|c|c|c|c|}
\hline $\begin{array}{l}\text { Sample } \\
\text { site }\end{array}$ & $\begin{array}{l}\text { Maceration } \\
\text { number }\end{array}$ & Coal & $\begin{array}{l}\text { Thick- } \\
\text { ness }(\mathrm{cm})\end{array}$ & $\begin{array}{l}\text { Abundance* } \\
\text { of algae }\end{array}$ & Location \\
\hline 1 & 1077 & Hermon & 10.2 & rare & $\begin{array}{l}\text { SE NW NW, Sec. 9, T.17N., R.1E., } \\
\text { Rock Island Co., IL }\end{array}$ \\
\hline 2 & 1865 & Brush & 3.8 & abundant & $\begin{array}{l}\text { NW NE SW, Sec. 15, T.11N., R.2W., } \\
\text { Warren Co., IL }\end{array}$ \\
\hline 3 & 2361D & Brush & 30.5 & rare & $\begin{array}{l}\text { Hole J-13, New Jersey Zinc Co., NW } \\
\text { NE NE SE, Sec. 7, T.10N., R.1E., } \\
\text { Knox Co., IL }\end{array}$ \\
\hline 4 & 1858 & Hermon & 35.6 & rare & $\begin{array}{l}\text { NW NE NE, Sec. 26, T.9N., R.1W., } \\
\text { Warren Co., IL }\end{array}$ \\
\hline 5 & $2278 C$ & Tarter & 10.2 & rare & $\begin{array}{l}\text { N-S line, SE SW SE, Sec. 11, T.7N., } \\
\text { R.1E., Fulton Co., IL }\end{array}$ \\
\hline 6 & $2402 \mathrm{~A}$ & Brush & 12.7 & rare & $\begin{array}{l}\text { SW SE SW, Sec. 10, T.6N., R.1E., } \\
\text { Fulton Co., IL }\end{array}$ \\
\hline 7 & 1923 & Tarter & 96.5 & unknown & SW, Sec. 34, T.6N., R.1E., Fulton Co., IL \\
\hline 8 & 2066 & Tarter & 25.4 & common & SE, Sec. 2, T.5N., R.1E., Fulton Co., IL \\
\hline 9 & 2187 & $\begin{array}{l}\text { Murphysboro } \\
\text { equivalent }\end{array}$ & 38 & rare & $\begin{array}{l}\text { SE SW NW, Sec. 10, T.20N., R.9W., } \\
\text { Warren Co., IN }\end{array}$ \\
\hline 10 & 1972B & Buffaloville & 10.2 & rare & $\begin{array}{l}\text { Hole C-18, Public Service Co. of } \\
\text { Indiana, Sec. 32, T.17N., R.9W., } \\
\text { Cayuga, Vermillion Co., IN }\end{array}$ \\
\hline 11 & 1973 & Lower Block & 12.7 & rare & $\begin{array}{l}\text { Hole C-19, Public Service Co. of } \\
\text { Indiana, Sec. 32, T.17N. R.9W., } \\
\text { Cayuga, Vermillion Co., IN }\end{array}$ \\
\hline 12 & $2308 \mathrm{C}$ & Delwood & 61 & rare & $\begin{array}{l}\text { Seegers Farm No. 1, Nat'l. Assoc. of } \\
\text { Petroleum, Sec. 2, T.9N., R.7E., } \\
\text { Cumberland Co., IL }\end{array}$ \\
\hline 13 & $2330 \mathrm{E}$ & Delwood & 61 & rare & $\begin{array}{l}\text { Wiyatt Farm No. 1, Texas Co., Sec. 6, } \\
\text { T.7N., R.10E., Jasper Co., IL }\end{array}$ \\
\hline 14 & 2247B & St. Meinrad & 40.6 & rare & $\begin{array}{l}\text { NW NW, Sec. 13, T.5N., R.5W., } \\
\text { Daviess Co., IN }\end{array}$ \\
\hline 15 & $2315 \mathrm{D}$ & Delwood & 91.4 & rare & $\begin{array}{l}\text { Schafer Farm No. 1, Kabana Co., NE } \\
\text { NE SW, Sec. 27, T.2N., R.12W., } \\
\text { Lawrence Co., IL }\end{array}$ \\
\hline 16 & $2310 \mathrm{~A}$ & Delwood & 30.5 & rare & $\begin{array}{l}\text { Nunn No. 1, Pure Oil Co., Sec. 17, } \\
\text { T.1S., R.8E., Wayne Co., IL }\end{array}$ \\
\hline
\end{tabular}


Table 1 Continued.

\begin{tabular}{|c|c|c|c|c|c|}
\hline $\begin{array}{l}\text { Sample } \\
\text { site }\end{array}$ & $\begin{array}{l}\text { Maceration } \\
\text { number }\end{array}$ & Coal & $\begin{array}{l}\text { Thick- } \\
\text { ness (cm) }\end{array}$ & $\begin{array}{l}\text { Abundance* } \\
\text { of algae }\end{array}$ & Location \\
\hline 17 & 1893B & Delwood & 91.4 & common & $\begin{array}{l}\text { B.L. Patrick No. 1, Robinson-Packett } \\
\text { Inc., SW NW, Sec. 14, T.5S., R.10E., } \\
\text { White Co., IL }\end{array}$ \\
\hline 18 & $1894 \mathrm{Ec}$ & New Burnside & 30.5 & rare & $\begin{array}{l}\text { Markham Hole 7A, Old Ben Coal } \\
\text { Co., Sec. 1, T.6S., R.2E., Franklin Co., IL }\end{array}$ \\
\hline 19 & $1123 \mathrm{~F}_{2}$ & Delwood & 8.9 & rare & $\begin{array}{l}\text { Hole 178, Bransford Co., SW cor. } \\
\text { NW, Sec. 1, T.8S., R.7E., Saline Co. IL }\end{array}$ \\
\hline 20 & $\begin{array}{l}1709, \\
1715\end{array}$ & New Burnside & 30.5 & rare & $\begin{array}{l}\text { SW SE NW, Sec. 30, T.10S., R.4E., } \\
\text { Williamson Co., IL }\end{array}$ \\
\hline 21 & $1054 \mathrm{~A}$ & Delwood & 24.8 & rare & $\begin{array}{l}\text { NE SE SW, Sec. 5, T.11S., R.4E., } \\
\text { Johnson Co., IL }\end{array}$ \\
\hline 22 & 1061 & Delwood & $?$ & common & $\begin{array}{l}\text { NW SE SW, Sec. 3, T.11S., R.4E., } \\
\text { Johnson Co., IL }\end{array}$ \\
\hline 23 & 1062 & Delwood & ? & rare & $\begin{array}{l}\text { SW NW SW, Sec. 3, T.11S., R.4E., } \\
\text { Johnson Co., IL }\end{array}$ \\
\hline 24 & 2897 & New Burnside & $?$ & abundant & $\begin{array}{l}\text { NE NW NW SE, Sec. 8, T.11S., } \\
\text { R.4E., Johnson Co., IL }\end{array}$ \\
\hline 25 & 2980 & unnamed & $?$ & rare & $\begin{array}{l}\text { SW NW SE NE, Sec. 21, T.11S., } \\
\text { R.3E., Johnson Co., IL }\end{array}$ \\
\hline 26 & 2611 & Bell & $?$ & rare & $\begin{array}{l}\text { NE.SW SW, Sec. 17, T.11S., R.4E., } \\
\text { Johnson Co., IL }\end{array}$ \\
\hline 27 & 3059 & Bell & ? & rare & $\begin{array}{l}\text { S. of Center NE, Sec. 26, T.11S., } \\
\text { R.2E., Johnson Co., IL }\end{array}$ \\
\hline 28 & 2695 & Reynoldsburg & 78.7 & abundant & $\begin{array}{l}\text { NE SE SW, Sec. 27, T.11S., R.4E., } \\
\text { Johnson Co., IL }\end{array}$ \\
\hline 29 & 1978 & Reynoldsburg & 30.5 & rare & $\begin{array}{l}\text { Center NW, Sec. 35, T.11S., R.4E., } \\
\text { Johnson Co., IL }\end{array}$ \\
\hline 30 & $1833 B$ & Delwood & 5 & rare & $\begin{array}{l}\text { SW NW NE, Sec. 4, T.11S., R.6E., } \\
\text { Pope Co., IL }\end{array}$ \\
\hline 31 & 2959 & Reynoldsburg & $?$ & rare & $\begin{array}{l}\text { 2,200' from N. line, } 1,800^{\prime} \text { from W. } \\
\text { line, Sec. 32, T.11S., R.6E., Pope Co., IL }\end{array}$ \\
\hline 32 & 2927 & Delwood & 12.7 & rare & $\begin{array}{l}\text { NE SE NW, Sec. 2, T.11S., R.6E., } \\
\text { Pope Co., IL }\end{array}$ \\
\hline 33 & $\begin{array}{l}2837 B^{*} \\
2837 \mathrm{~A}\end{array}$ & $\begin{array}{l}\text { Delwood } \\
\text { Delwood }\end{array}$ & $\begin{array}{l}12.7 \\
25.4\end{array}$ & $\begin{array}{l}\text { abundant } \\
\text { rare }\end{array}$ & $\begin{array}{l}\text { NE cor. SE NW, Sec. 27, T.10S., R.6E., } \\
\text { Saline Co., IL }\end{array}$ \\
\hline 34 & $2994 \mathrm{~A}$ & Delwood & 45.7 & rare & $\begin{array}{l}\text { Hole No. H-1, ISGS, } 1,400^{\prime} \text { from S. line, } \\
2,300^{\prime} \text { from E. line, Sec. } 20, T .10 S ., \text { R.6E., } \\
\text { Saline Co., IL }\end{array}$ \\
\hline
\end{tabular}


Table 1 Continued.

\begin{tabular}{|c|c|c|c|c|c|}
\hline $\begin{array}{l}\text { Sample } \\
\text { site }\end{array}$ & $\begin{array}{l}\text { Maceration } \\
\text { number }\end{array}$ & Coal & $\begin{array}{l}\text { Thick- } \\
\text { ness }(\mathrm{cm})\end{array}$ & $\begin{array}{l}\text { Abundance* } \\
\text { of algae }\end{array}$ & Location \\
\hline 35 & $\begin{array}{l}1958 D \\
1958 C\end{array}$ & $\begin{array}{l}\text { Lewisport } \\
\text { Lewisport }\end{array}$ & $\begin{array}{l}3.2 \\
3.2\end{array}$ & $\begin{array}{l}\text { abundant } \\
\text { abundant }\end{array}$ & $\begin{array}{l}23,000^{\prime} \text { from } N \text {. line, } 11,900^{\prime} \text { from } W . \\
\text { line, DeKoven Quad., Union Co., KY }\end{array}$ \\
\hline 36 & 25671 & Delwood & 30 & rare & $\begin{array}{l}\text { Hole Gil 15, KY Geol. Surv., Carter } \\
\text { Coor. 5-M-18, 2,100' from W. line, } \\
1,950^{\prime} \text { from S. line, Dekoven Quad., } \\
\text { Union Co., KY }\end{array}$ \\
\hline 37 & 2186 & Lewisport & 122 & rare & $\begin{array}{l}\text { Black Gold Mine, } 300^{\prime} \text { from N. line, } \\
1,500^{\prime} \text { from E. line, Carter Coor. 16- } \\
\text { H-24, Christian Co., KY }\end{array}$ \\
\hline 38 & $2175 C$ & Lewisport & 35.6 & rare & $\begin{array}{l}\text { Whittington Mine, } 3,000^{\prime} \text { from } \mathrm{N} \text {. } \\
\text { line, 1,600' from E. line, Carter } \\
\text { Coor. } 21-\mathrm{H}-24 \text {, Christian Co., KY }\end{array}$ \\
\hline 39 & 1799 & Dawson Spr & 50.8 & rare & $\begin{array}{l}3 / 4 \text { mile NE Mining City, elbow of } \\
\text { Green River, Dunmore Quad., } \\
\text { Butler Co., KY }\end{array}$ \\
\hline 40 & 1869 & Dunbar & $?$ & rare & $\begin{array}{l}2,000^{\prime} \text { from S. line, } 1,900^{\prime} \text {, from E. line, } \\
\text { Carter Coor. 13-I-34, Butler Co., KY }\end{array}$ \\
\hline 41 & $\begin{array}{l}2180 B^{*} \\
2180 A\end{array}$ & $\begin{array}{l}\text { Bancroft? } \\
\text { Lewisport }\end{array}$ & $\begin{array}{l}45.7 \\
22.9\end{array}$ & $\begin{array}{l}\text { rare } \\
\text { abundant }\end{array}$ & $\begin{array}{l}\text { Green River Parkway, } 16,000^{\prime} \text { from } \\
\text { W. line, } 18,500^{\prime} \text { from S. line, } \\
\text { Horton Quad., Ohio Co., KY }\end{array}$ \\
\hline 42 & 1540 & Breckinridge & $?$ & abundant & $\begin{array}{l}5 \text { miles S. of Cloverport, } \\
\text { Breckinridge Co., KY }\end{array}$ \\
\hline 43 & 2205 & Mariah Hill & 35.6 & common & $\begin{array}{l}\text { NW SE NW, Sec. 20, T.6S., R.4W., } \\
\text { Spencer Co., IN }\end{array}$ \\
\hline
\end{tabular}

- Number of specimens of Botryococcus per slide rare: less than 1 to 10 ; common: 11 to 60 ; abundant: more than 60

- Overlies the sample listed immediately below (at the same site) 


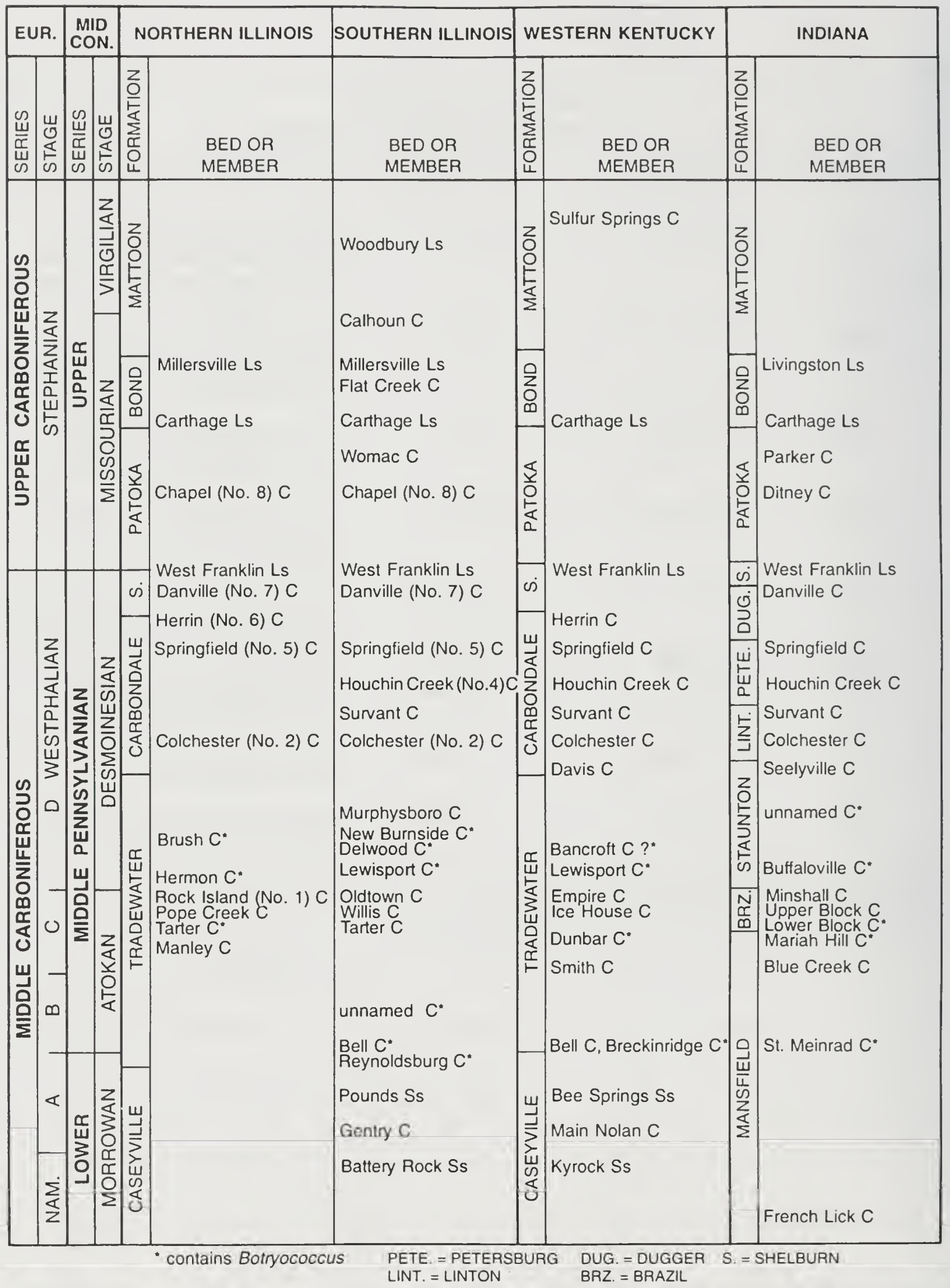

Figure 3 Stratigraphic and geographic occurrences of Botryococcus in the Illinois Basin. The alga has been found in uppermost Morrowan to lower Desmoinesian coal beds. 
borne by small lycopods, make up most of the remaining spore assemblage in maceration 3059.

Maceration 2247B (site 14), which contains rare specimens of Botryococcus, is from the upper of two coal beds in Daviess County, Indiana, which Guennel (sample site 58a, 1958) reported as the Upper Block Coal Member. Hutchison (1971) mapped the coal as an unnamed coal in the Mansfield Formation. Spore analysis of the coal indicates that it is probably equivalent to the St. Meinrad Coal Member, which is in the Mansfield Formation. Its spore assemblage is diverse, but $97 \%$ of the spores are Lycospora.

\section{Unnamed Coal Bed (Illinois)}

The coaly shale that crops out just above a pebbly sandstone at site 25 (table 1 ) is probably early Atokan in age and a little younger than the Bell Coal. The coal contains rare specimens of Botryococcus, and its spore assemblage is greatly dominated $(88.5 \%)$ by Lycospora.

\section{Mariah Hill Coal Member (Indiana) and Dunbar Coal Bed (Kentucky)}

Algae are common at site 43 of the Mariah Hill Coal Member in Spencer County, Indiana, along the bluff of the Ohio River (table 1, fig. 2). The location is the same as sample site No. 943-1, 2 of Cooper (1946) and site 30 of Shaver and Smith (1974), who studied ostracodes from overlying shale just below the Ferdinand Limestone (now part of the Lead Creek Limestone Member). The Dunbar coal bed in Kentucky, which correlates to the Mariah Hill Coal, contains only rare specimens of Botryococcus at site 40 , about 1 mile southwest of Morgantown. Both samples are dominated by Lycospora. Radiizonates difformis and $R$. rotatus, both borne by herbaceous lycopods, are fairly common.

\section{Tarter Coal Member (Illinois) and Lower Block Coal Member (Indiana)}

Kosanke (1951) described a boghead coal in the upper few centimeters of the Tarter Coal Member at site 7 in Fulton County. He reported about $33 \%$ algae and $24 \%$ anthraxylon (vitrinite) on the basis of his study of thin sections. Botryococcus was not observed in the coal below the top few centimeters (maceration 1923). Boghead algae are common in the Tarter Coal at site 8, the type section of the coal, which is only about $2.4 \mathrm{~km}$ southeast of the coal at site 7. Maceration 2278C (site 5), which contains rare specimens of Botryococcus, is also from Fulton County and represents the Tarter Coal where it is only $10.2 \mathrm{~cm}$ thick. Maceration 1973 of a $12.7-\mathrm{cm}$-thick previously unnamed coal, which contains rare specimens of Botryococcus, is from a core drilled at site 11 near Cayuga, Vermillion County, Indiana. The great abundance of Lycospora (72.5\%) and the presence of Zosterosporites, Endosporites zonalis, and Radiizonates difformis indicate that this coal is equivalent to the Lower Block Coal.

\section{Hermon Coal Member (Illinois)}

Algae are rare in the Hermon Coal Member, which is $1.5 \mathrm{~m}$ above the Seville Limestone Member at site 4 in Warren County, Illinois. The spore assemblage is diverse and mostly composed of fern and sphenopsid spores and only $1 \%$ Lycospora. Botryococcus is also rare at site 1 (Rock Island County), where the coal is about $0.6 \mathrm{~m}$ above the Rock Island (No. 1) Coal Member.

\section{Brush Coal Member (Illinois)}

Botryococcus is very abundant in the Brush Coal Member at site 2 in Warren County. The coal is only $3.8 \mathrm{~cm}$ thick and about $0.9 \mathrm{~m}$ above the Hermon Coal (fig. 3). Because the spore assemblage in maceration 1865 is very poorly preserved, composition of the coal swamp flora could not be determined. Botryococcus is very rare in the Brush Coal at site 3 in Knox County. The spore assemblage is dominated by Lycospora ( $52 \%)$, but fern spores $(36 \%)$ are well represented. The alga is also rare in a core sample of the coal at site 6 in Fulton County. The spore assemblage in the coal, which is only $12.7 \mathrm{~cm}$ thick, is greatly dominated by Lycospora $(75 \%)$.

\section{Buffaloville Coal Member (Indiana) and Lewisport Coal Bed (Kentucky)}

A coal about $10.2 \mathrm{~cm}$ thick from a core drilled at site 10 near Cayuga, Indiana, is tentatively correlated with the Buffaloville Coal Member. Algae are rare in the coal that is dominated by Lycospora $(52 \%)$. Botryococcus is also rare in three samples of the Lewisport coal in Kentucky, which correlates with the Buffaloville Coal. In maceration 1799 of the coal near Mining City, Lycospora makes up $45 \%$ of the spore assemblage, and fern spores account for $26 \%$. Botryococcus is rare in the Lewisport coal at sites 37 and 38. The coal in the Black Gold Mine at site 37 in Christian County contains more fern spores (46.5\%) than Lycospora (21\%). Fern spores account for half the spore assemblage in the coal from the high wall of the Whittington Mine at site 38 .

Algae are very abundant in the Lewisport coal at sites 35 and 41 in Union and Ohio Counties. The underclay and overlying shale at site 35 also contain Botryococcus and will be discussed later. Maceration 2180A from the 23-cm-thick Lewisport coal at site 41 is dominated by spores produced by lycopods: $32.5 \%$ Lycospora and $20 \%$ Granasporites medius (fig. 4 ).

\section{Bancroft(?) Coal Bed (Kentucky)}

Botryococcus is rare in a coal tentatively correlated with the Bancroft coal bed. The coal (maceration 2180B) at site 41 is overlain by cherty limestone and is about $3 \mathrm{~m}$ above the Lewisport coal, which contains abundant algae.

\section{Delwood Coal Bed (Illinois) and Equivalent Coal in Kentucky}

Botryococcus was observed in the Delwood Coal Bed and equivalent coals at 14 sites (table 1 ). It is abundant 


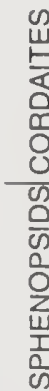

-dds sə!̣u!̣ol
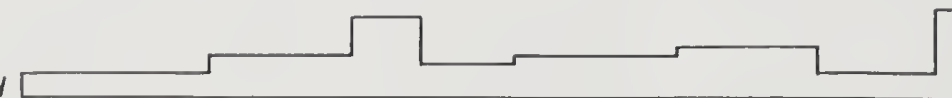

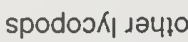

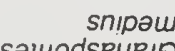

\begin{tabular}{l} 
n \\
0 \\
0 \\
0 \\
0 \\
\hdashline
\end{tabular}
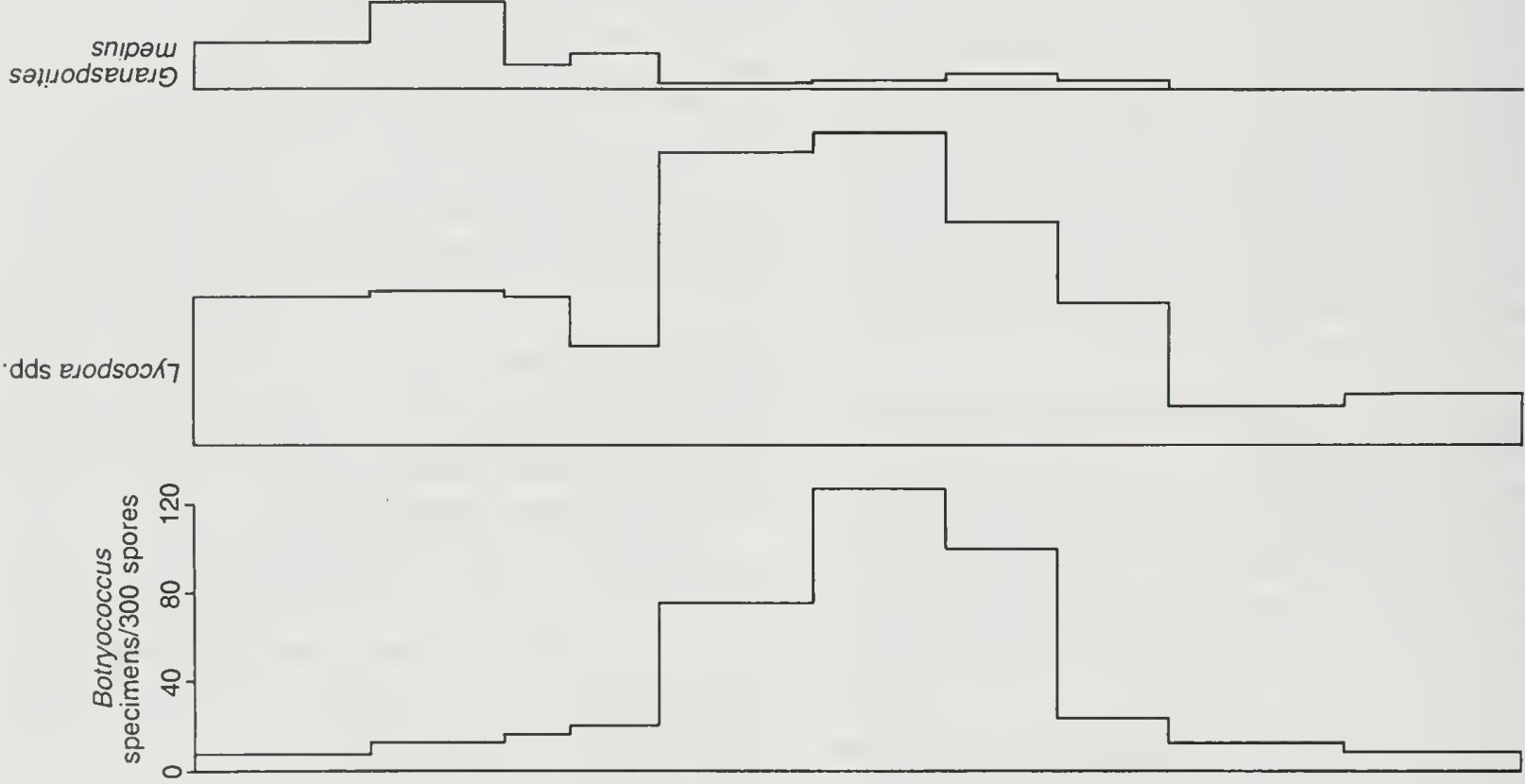

ə|dues
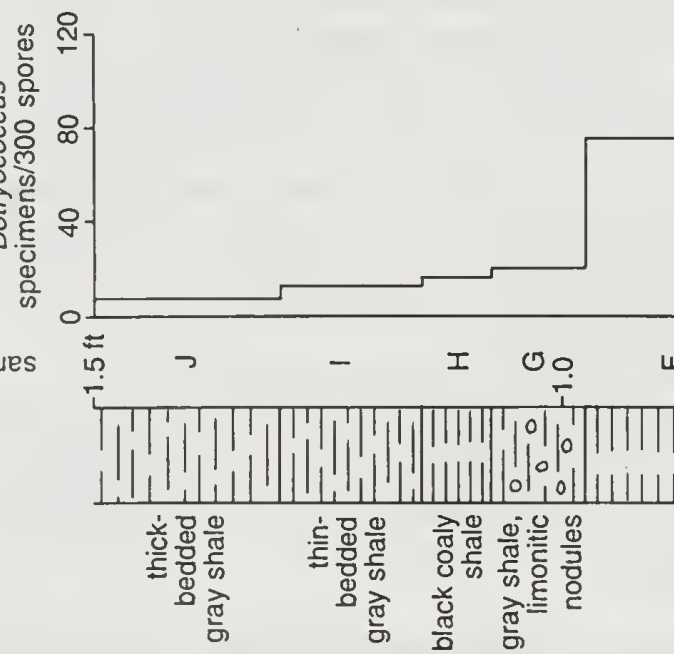

ᄂ
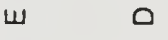

กับ

$\infty$ 
at one site and common at two. Lycospora is very abundant in the Delwood Coal and commonly makes up more than two-thirds of the spore assemblage. Rare specimens of Botryococcus were observed in the carbonaceous shale band in the Delwood Coal at site 30, which is less than $2.6 \mathrm{~km}$ from its type section at NW NW, Sec. 3, T.11S., R.6E., Pope County. The coal at site 32 , also about $2.6 \mathrm{~km}$ from the type section, contains rare speciments of Botryococcus.

The geologic map of the Eddyville Quadrangle (Nelson and Lumm 1990) places the coal at site 32 in the lower part of the Abbott Formation (now called the Tradewater Formation). Palynological evidence, however, would place the coal in the upper part of the Tradewater Formation because the most abundant $L y$ cospora is L. granulata rather than L. pellucida (Peppers 1996) and Laevigatosporites globosus is common. It also contains Vestispora clara, V. fenestrata, V. wanlessii, Camptotriletes confertus, Triquitrites pulvinatus, and $T$. sculptilis, which do not appear until the middle part of the Tradewater. This disagreement between the mapped and palynological age of the coal cannot be resolved until more samples are obtained.

The Delwood Coal from diamond-drilled cores at sites 19 and 34 in Saline County contains rare specimens of Botryococcus. Maceration 1123 F2 is from the middle $8.9 \mathrm{~cm}$ of the $42-\mathrm{cm}$-thick coal, and the coal of maceration $2994 \mathrm{~A}$ is $45.7 \mathrm{~cm}$ thick. At site 33 in Saline County, the upper part of the coal contains abundant Botryococcus. Lycospora accounts for $57 \%$ of the spore assemblage, and Laevigatosporites is second in abundance at $24 \%$.

In Johnson County, Botryococcus is rare in the Delwood Coal at sites 21 and 23. Maceration $1054 \mathrm{~A}$ at site 21 represents the top $24.8 \mathrm{~cm}$ of a $49-\mathrm{cm}$-thick coal. The coal at site 23 is less than $0.8 \mathrm{~km}$ from the coal at site 22, in which Botryococcus is common. The spore assemblage at site 22 is greatly dominated by Lycospora at $85 \%$.
Some of the samples of the Delwood Coal are from rotary-drill cuttings of coal that extends into the deeper parts of the Illinois Basin. Algae are rare in the coal at sites 12, 13, 15, and 16 in Cumberland, Jasper, Lawrence, and Wayne Counties. Botryococcus is common in the Delwood Coal at site 17 in White County, where Lycospora accounts for $68.5 \%$ of the spore assemblage, and fern spores account for $27.5 \%$ (table 2 ).

Botryococcus is rare in a coal correlated with the Delwood Coal at 322.2 to $323.2 \mathrm{ft}$ in Western Kentucky Test Hole Gil 15 (Williams et al. 1982) at site 36 in Union County, Kentucky.

\section{New Burnside Coal Bed (Illinois)}

The New Burnside Coal Bed is generally 4.6 to $7.6 \mathrm{~m}$ above the Delwood Coal Bed. Botryococcus is rare in the $30.5-\mathrm{cm}$-thick canneloid coal at sample site 20 . The spore assemblage contains an unusually large abundance (23\%) of Endosporites globiformis, which was produced by lycopods of small stature. Endosporites seldom accounts for more than $10 \%$ of spore assemblages in Lower and Middle Pennsylvanian coal beds. A coal from a diamond-drilled core at site 18 that contains rare specimens of Botryococcus correlates with the New Burnside Coal. Botryococcus is abundant in maceration 2897 of a core sample from site 24 in Johnson County, but the spores are poorly preserved. The drill hole is about $2.6 \mathrm{~km}$ west of the town of New Burnside, and the New Burnside Coal is about $15.3 \mathrm{~m}$ below the Murphysboro Coal Member.

\section{Unnamed Coal (Indiana) Equivalent to the Murphysboro Coal Member (Illinois)}

A coal correlated with the Murphysboro Coal Member at site 9 in Warren County, Indiana, contains occasional specimens of Botryococcus. This coal also contains coal balls near Cayuga in Fountain County, Indiana (Phillips 1980).

\section{ALGAL AND SPORE ABUNDANCE IN THE LEWISPORT COAL BED AND OVERLYING AND UNDERLYING STRATA IN UNION COUNTY, KENTUCKY}

Strata above and below the Lewisport coal bed at site 35 were sampled to learn whether abundance of Botryococcus is related to composition of spore assemblages (fig. 5). The Lewisport coal is poorly exposed on the southwest slope of Indian Hill in Union County, Kentucky. It is only $6.4 \mathrm{~cm}$ thick and divided into upper and lower benches. Only the top $33 \mathrm{~cm}$ of underclay is exposed. Above the coal lies $8.3 \mathrm{~cm}$ of black coaly shale, then $2.5 \mathrm{~cm}$ of dark gray shale with limonite nodules, $2 \mathrm{~cm}$ black coaly shale, and finally $17.5 \mathrm{~cm}$ of medium gray shale. Estimated Botryococcus abundance was obtained by counting the number of algal colonies or parts of colonies in proportion to 300 spores, regardless of whether the spore was well enough preserved to be identified.

Botryococcus was rare during deposition of clay that formed the seat earth for the Lewisport peat swamp, but it increased slightly in abundance during the later stage of development (fig. 5, maceration 1958B). It doubled in abundance during deposition of the bottom half of the peat, became very abundant in the upper half, and reached its peak abundance in the muddy peat overlying the peat bed. Botryococcus was still abundant but diminished somewhat toward the later part of deposition of carbonaceous mud. Algal abundance abruptly decreased at the beginning of deposition of less carbonaceous mud (gray shale with limonitic nodules) and continued to decline through the rest of the sampled sequence and into deposition of an upper thin peaty mud (maceration $1958 \mathrm{H}$ ).

There is a good correlation between abundance of Botryococcus and Lycospora, borne by Lepidophloios and other lycopod trees. From the top of the underclay to the bottom half of the peat bed, Lycospora gradually triples in abundance while Botryococcus doubles in 
Table 2 Palynology of selected coal samples in which Botryococcus is common or abundant. Numbers are percentage of species in the assemblage, and $X$ indicates species is present in maceration but was not observed during abundance count.

\begin{tabular}{|c|c|c|c|c|c|c|c|}
\hline Spore taxa & $\begin{array}{c}\text { Mariah } \\
\text { Hill } \\
2205\end{array}$ & $\begin{array}{c}\text { Tarter } \\
2066\end{array}$ & \multicolumn{2}{|c|}{ Delwood } & $\begin{array}{c}\text { Lewisport } \\
2180 \mathrm{~A}\end{array}$ & $\begin{array}{c}\text { Lower } \\
\text { Delwood } \\
2837 A^{*}\end{array}$ & $\begin{array}{c}\text { Upper } \\
\text { Delwood } \\
2837 \mathrm{~B}\end{array}$ \\
\hline Deltoidospora levis & & & $x$ & $x$ & & & \\
\hline D. priddyi & & & & & $x$ & & \\
\hline Punctatisporites flavus & $x$ & & & & $x$ & & \\
\hline P. minutus & & & 2.0 & & & 0.5 & 0.5 \\
\hline Calamospora breviradiata & 1.5 & 1.0 & & & 1.5 & & 1.5 \\
\hline C. hartungiana & & & $x$ & & $X$ & 0.5 & \\
\hline C. straminea & & 0.5 & & & & & \\
\hline Granulatisporites adnatoides & & 1.5 & & & & $x$ & \\
\hline G. granularis & & 0.5 & & & 0.5 & & \\
\hline G. granulatus & & & & & & & 0.5 \\
\hline G. pallidus & & & 0.5 & & & & \\
\hline G. verrucosus & & & & & & 1.0 & 1.0 \\
\hline G. spp. & & & & & & 1.0 & \\
\hline Cyclogranisporites aureus & 0.5 & $x$ & $x$ & $x$ & $x$ & 0.5 & 0.5 \\
\hline C. microgranus & & & $X$ & & 0.5 & 0.5 & \\
\hline C. minutus & & 3.0 & & & $X$ & $X$ & \\
\hline Verrucosisporites microtuberosus & 1.5 & $x$ & & & $x$ & & $x$ \\
\hline$V$. sifati & $x$ & $x$ & & & & & \\
\hline V. verrucosus & 0.5 & & & & & & \\
\hline$V$. cf. verrucosus & $x$ & & & & & & \\
\hline$V$. spp. & & & 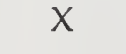 & & $\mathrm{X}$ & & \\
\hline Kewaneesporites patulus & & & & & $x$ & & \\
\hline Lophotriletes commissuralis & & 1.5 & & & & & \\
\hline L. copiosus & & & & & $x$ & & \\
\hline L. microsaetosus & & 0.5 & & & $x$ & 1.0 & \\
\hline L. mosaicus & & & $x$ & & & & \\
\hline L. pseudaculeatus & & & & & $x$ & & \\
\hline L. rarispinosus & & & 0.5 & & & & \\
\hline Anapiculatisporites minor & $x$ & & & & & & \\
\hline A. spinosus & $\mathrm{x}$ & & & $x$ & 0.5 & & \\
\hline Apiculatasporites spinososaetosis & $x$ & $x$ & & & & & \\
\hline A. spinulistratus & & & & & & $x$ & \\
\hline A. sp. & & & & & 0.5 & & \\
\hline Planisporites granifer & $\mathrm{X}$ & $x$ & & & & & \\
\hline Pilosisporites sp. & & 0.5 & & 1.0 & & & \\
\hline Raistrickia breveminens & & $x$ & & & $x$ & $x$ & \\
\hline R. crocea & 0.5 & $x$ & $x$ & & & & \\
\hline Spackmanites habibii & & & & & $x$ & & \\
\hline Convolutispora florida & $x$ & & & & & & \\
\hline C. sp. & 0.5 & & $X$ & & & & \\
\hline
\end{tabular}


Table 2 Continued.

\begin{tabular}{|c|c|c|c|c|c|c|c|}
\hline Spore taxa & $\begin{array}{c}\text { Mariah } \\
\text { Hill } \\
2205\end{array}$ & $\begin{array}{l}\text { Tarter } \\
2066\end{array}$ & $\frac{\text { Del }}{1893 B}$ & $\frac{\mathrm{od}}{1061}$ & $\begin{array}{l}\text { Lewisport } \\
2180 \mathrm{~A}\end{array}$ & $\begin{array}{c}\text { Lower } \\
\text { Delwood } \\
2837 A^{*}\end{array}$ & $\begin{array}{c}\text { Upper } \\
\text { Delwood } \\
2837 \mathrm{~B}\end{array}$ \\
\hline Microreticulatisporites concavus & & $x$ & & & & & \\
\hline $\begin{array}{l}\text { M. harrisonii } \\
\text { M. nobilis }\end{array}$ & & & $x$ & $\mathrm{X}$ & & 05 & \\
\hline M. sulcatus & & & 0.5 & & & $\mathrm{X}$ & $x$ \\
\hline Dictyotriletes bireticulatus & 0.5 & $x$ & & & & & \\
\hline Camiptotriletes confertus & & & $x$ & & & $x$ & \\
\hline Triquitrites additus & & & & & & $x$ & \\
\hline T. bransonii & & 0.5 & $X$ & 1.0 & 0.5 & 1.0 & 3.0 \\
\hline T. exiguus & & & $x$ & $\mathrm{x}$ & & $X$ & 0.5 \\
\hline T. minutus & & & & & & $X$ & \\
\hline T. pulvinatus & & & $X$ & & & X & \\
\hline T. sculptilis & & 3.0 & & $X$ & & 0.5 & 0.5 \\
\hline T. spp. & & & 0.5 & & & & \\
\hline Reinschospora magnifica & $x$ & $x$ & & & & & \\
\hline R. triangularis & & & & & $X$ & & \\
\hline Knoxisporites stephanephorus & $\mathrm{X}$ & & $X$ & & $\mathrm{X}$ & & \\
\hline $\begin{array}{l}\text { Reticulatisporites } \\
\text { mediareticulatus }\end{array}$ & & & & & $\mathrm{X}$ & & \\
\hline R. polygonalis & $x$ & & & & & & \\
\hline R. reticulatus & 1.5 & $X$ & & & & & \\
\hline R. reticulocingulum & $\mathrm{X}$ & & & & & & \\
\hline Crassispora kosankei & $x$ & 0.5 & 2.5 & 0.3 & 1.0 & $x$ & \\
\hline Granasporites medius & 4.5 & $\mathrm{x}$ & 7.0 & & 20.0 & $x$ & \\
\hline Murospora kosankei & & & $\mathrm{X}$ & & & $X$ & \\
\hline Densosporites annulatus & $X$ & & & & & & \\
\hline D. sphaerotriangularis & 0.5 & $x$ & $x$ & & & & \\
\hline Lycospora granulata & 44.5 & 48.0 & 9.5 & 59.3 & 23.0 & 25.0 & 45.0 \\
\hline L. micropapillata & & & 0.5 & 0.7 & 2.0 & 0.5 & \\
\hline L. orbicula & 0.5 & & & & & & \\
\hline L. pellucida & 1.0 & $X$ & 48.0 & 24.3 & 5.5 & 34.0 & 2.5 \\
\hline L. pusilla & & 0.5 & 15.0 & & 1.5 & 18.5 & 9.5 \\
\hline L. rotunda & 1.0 & 0.5 & 0.5 & $x$ & 0.5 & $x$ & \\
\hline L.subjuga & & 0.5 & & & & & \\
\hline Cristatisporites indignabundus & & $x$ & & & & & \\
\hline Cirratriradites maculatus & & $x$ & $x$ & & & & \\
\hline C. sp. & $x$ & $X$ & & & & & \\
\hline Radiizonates difformis & $x$ & & & & & & \\
\hline R. rotatus & 5.5 & $X$ & & & & & \\
\hline $\begin{array}{l}\text { Endosporites globiformis } \\
\text { E. plicatus }\end{array}$ & & $x$ & $\begin{array}{l}x \\
X\end{array}$ & 2.3 & 9.0 & 0.5 & 6.0 \\
\hline E. zonalis & & $x$ & & & & & \\
\hline
\end{tabular}


Table 2 Continued.

\begin{tabular}{|c|c|c|c|c|c|c|c|}
\hline \multirow[b]{2}{*}{ Spore taxa } & \multirow{2}{*}{$\begin{array}{c}\text { Mariah } \\
\text { Hill } \\
2205\end{array}$} & \multirow{2}{*}{$\begin{array}{c}\text { Tarter } \\
2066\end{array}$} & \multicolumn{2}{|c|}{ Delwood } & \multirow{2}{*}{$\begin{array}{c}\text { Lewisport } \\
2180 \mathrm{~A}\end{array}$} & \multirow{2}{*}{$\begin{array}{c}\text { Lower } \\
\text { Delwood } \\
2837 A^{*}\end{array}$} & \multirow{2}{*}{$\begin{array}{c}\text { Upper } \\
\text { Delwood } \\
2837 \mathrm{~B}\end{array}$} \\
\hline & & & 1893B & 1061 & & & \\
\hline Alatisporites hexalatus & & & & & & & $x$ \\
\hline A. hoffmeisterii & & $X$ & & & & & \\
\hline A. pustulatus & $X$ & $x$ & & & & & \\
\hline A. trialatus & & $x$ & & & & & \\
\hline Hymenospora multirugosa & $X$ & & & & & & \\
\hline Laevigatosporites desmoinesensis & 3.5 & & 1.0 & & $x$ & 6.5 & 14.5 \\
\hline L. globosus & 3.0 & 16.0 & 1.0 & 1.0 & 27.5 & 2.5 & 4.0 \\
\hline L. medius & $x$ & $x$ & & & 1.0 & & \\
\hline L. ovalis & 16.5 & 4.0 & 3.5 & 4.0 & 3.0 & 1.0 & 5.5 \\
\hline L. punctatus & & 9.0 & & & & & \\
\hline L. striatus & & & & $x$ & & & \\
\hline L. vulgaris & & 0.5 & $x$ & & $x$ & & $x$ \\
\hline L. sp. & & & & & $x$ & & \\
\hline Punctatosporites minutus & 0.5 & 2.5 & 2.0 & 4.0 & 0.5 & 5.5 & 4.5 \\
\hline Spinosporites exiguus & & 0.5 & & & & & \\
\hline Thymospora pseudothiessenii & & & & & $x$ & & \\
\hline Torispora securis & & 3.5 & $x$ & & $x$ & $x$ & $x$ \\
\hline Vestispora clara & & & & & & $x$ & $x$ \\
\hline V. costata & & $x$ & & & & & \\
\hline$V$. fenestrata & & $x$ & 0.5 & 0.3 & 0.5 & $x$ & $x$ \\
\hline$V$. laevigata & & & & & $x$ & & \\
\hline V. pseudoreticulata & $\mathrm{X}$ & & & & $x$ & & \\
\hline V.wanlessii & & & $x$ & & & & \\
\hline Florinites mediapudens & 2.0 & 1.5 & 4.0 & 0.3 & & & 0.5 \\
\hline F. millotti & & & & 0.7 & $x$ & & \\
\hline F. similis & & & $x$ & & $x$ & & \\
\hline F. volans & $x$ & & & & & & $x$ \\
\hline Wilsonites circularis & & $x$ & & & $x$ & & \\
\hline W. delicatus & & & $x$ & & 0.5 & & \\
\hline W. vesicatus & & & 1.0 & & 0.5 & $x$ & \\
\hline Trihyphaecites triangulatus & & & & & $x$ & & \\
\hline
\end{tabular}

*Although Botryococcus is rare in the lower part of the coal (maceration 2837A), it is common in the upper part (maceration 2837B). 


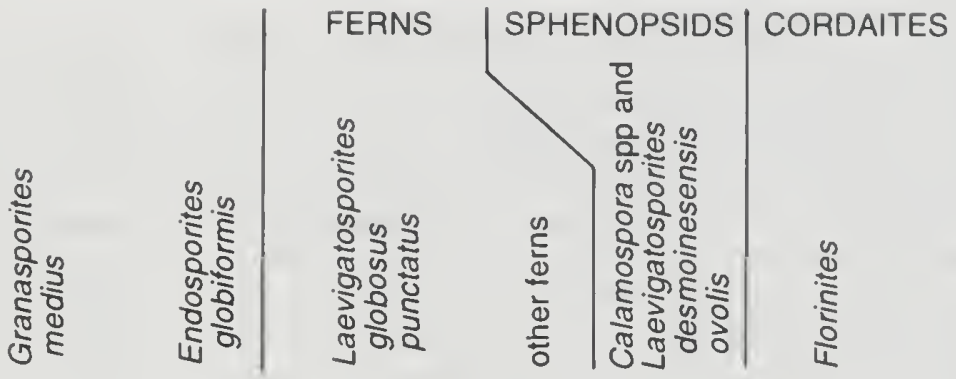

Delwood (mac $2837 \mathrm{~A} / \mathrm{B})$
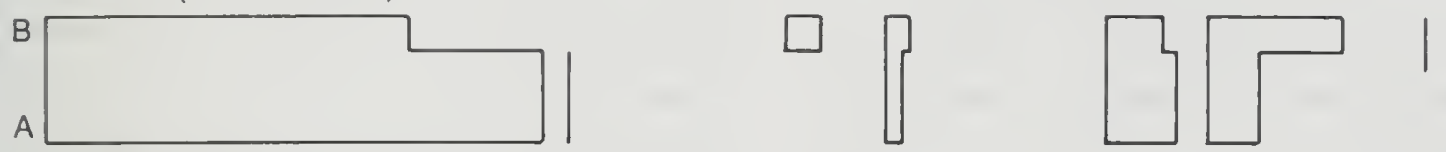

Lewisport (mac $2180 \mathrm{~A})$
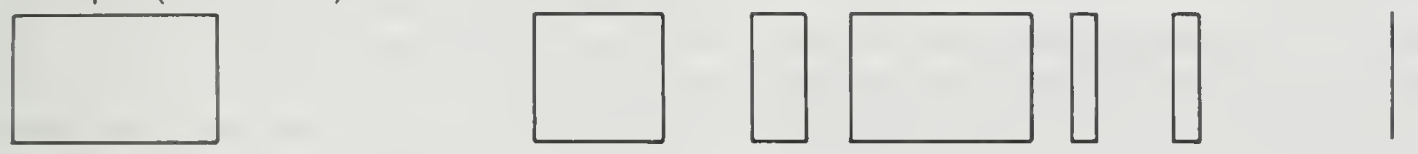

Tarter (mac 2066)
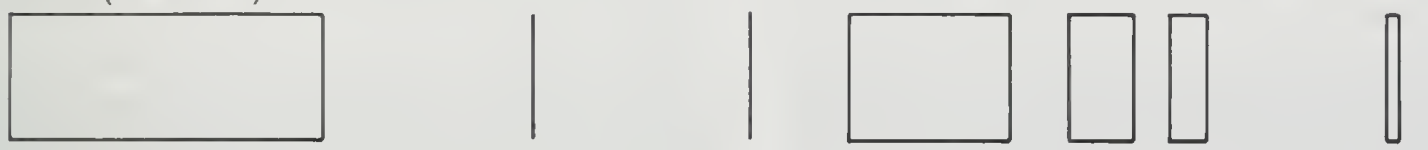

Mariah Hill (mac 2205)
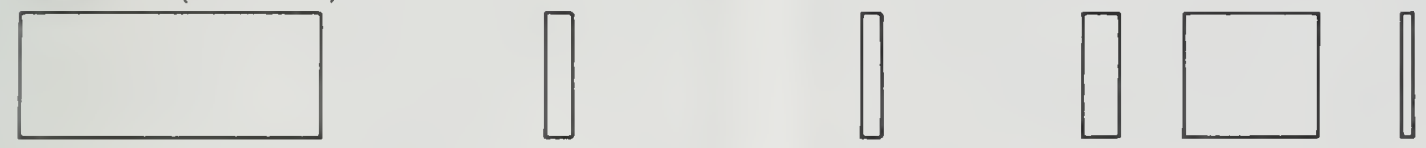

Figure 5 Relative abundance of spore taxa in representative coal beds, from oldest at the base to youngest at top, in which Botryococcus is abundant or common. Lycospora was borne by lycopod trees, which were most abundant on substrates that were very wet to flooded.

abundance (fig. 4). Lycopsids continued to increase in abundance in the top half of the peat and reached their peak abundance (maceration 1958E) in the overlying peaty mud. Lycopsid abundance sharply declined during deposition of the overlying iron-rich mud, but then remained at about $30 \%$ of the spore assemblages in the gray shale environments that followed. Diaphorodendron and Synchysidendron represented by Granasporites medius were very rare during deposition of the underclay and were rare in the peat swamp and overlying more-clastic peat (macerations $1958 \mathrm{E}$ and F). Diaphorodendron became more common during deposition of the gray mud (macerations 1958 I and J). Other lycopods played a minor role in the floras. Chaloneria is well represented in the peat, judging from the 5\% Endosporites in the coal. Crassispora, produced by Sigillaria, reached a maximum of only $3 \%$ of the spore assemblage in the organic-rich mud (macerations $1958 \mathrm{E}$ and F) and limonitic mud (maceration 1958G) overlying the coal. Densosporites, borne by small herbaceous lycopods, was most abundant $(4 \%)$ in the thin-bedded gray shale environment (maceration 1958I).
Ferns dominated the environment of clay deposition that formed the seat earth of the peat swamp. The most abundant fern spores, Laevigatosporites globosus, are from scolecopterid tree ferns. Triquitrites, which was probably produced by filicalean ferns, is also abundant. Most of the remaining fern spores including Granulatisporites, Lophotriletes, Raistrickia, and Apiculatasporites were also derived from filicalean ferns. Ferns diminished in importance later in the peat swamp and overlying clastic wet environments except where they became slightly more abundant during deposition of the less carbonaceous mud (macerations $1958 \mathrm{G}$ through J).

Sphenopsid plants were abundant during deposition of what became the underclay, but unlike ferns, they were also a major part of the peat flora. Sphenopsids were a minor constituent in the overlying peaty mud environment, but they increased abruptly in importance during deposition of the gray mud (maceration 1958G), overlying black peaty mud (maceration $1958 \mathrm{H}$ ) and gray mud (macerations $1958 \mathrm{I}$ and J).

Cordaites were not common in the seat earth environment but were well represented during the early 
development of the peat swamp (maceration 1958C). These cordaites were adapted to the very wet environments, in contrast to those living on drier, better drained substrate (Phillips et al. 1985).

In the section of the Lewisport coal studied in detail, Botryococcus and Lycospora are most abundant in the coal and overlying black coaly shale. Modern Botryococcus lives in temperate to tropical, fresh and brackish aquatic environments. Lepidophloios and other lycopod trees that produced Lycospora were also adapted to very wet habitats (Phillips and Peppers 1984, Phillips et al. 1985, DiMichele and Phillips 1985, DiMichele et al. 1985). Diaphanodendron, Sigillaria, Chaloneria, and most ferns were adapted to drier or periodically drier habitats, where Botryococcus is not likely to thrive. Whether the water was fresh or brackish is not known.

Other coals in which Botryococcus is common or abundant include the Reynoldsburg, Breckinridge, Mariah Hill, Tarter, Brush, and Delwood. Spores in the sample of the Reynoldsburg Coal that was studied were not sufficiently well preserved to permit making a complete spore analysis. On the basis of spore analysis of other samples of the Reynoldsburg Coal (unpublished data), we found that Lycospora is most abundant and Densosporites (spores from herbaceous lycopods) is second in abundance. The latter is usually most abundant toward the top of coals, which suggests that the peat was still moist but less frequently covered by water during the last stage of peat swamp development
(Smith 1957, Smith and Butterworth 1967). Spores in maceration 1540 of the Breckinridge coal are also poorly preserved, but the spore assemblage is most similar to what is probably its correlative, the Bell coal bed (unpublished data). Lycospora greatly dominates the spore assemblages in the Bell coal and is very abundant in the Mariah Hill and Tarter Coals (fig. 5), which also locally contain abundant Botryococcus. Densosporites and Radiizonates (from herbaceous lycopods) are well represented in the Mariah Hill Coal (maceration 2205, table 2) but are rare in the Tarter Coal (maceration 2066, table 2). Maceration 1865 of the Brush Coal contains abundant Botryococcus; Lycospora is also abundant, but spores in the maceration are poorly preserved.

Algae have not been observed in the Pope Creek and Rock Island Coals and equivalent coals in Indiana, which lie between the Tarter and Brush Coals (fig. 3). The Pope Creek and Rock Island Coals contain spore populations that are dominated by fern spores. Ferns were abundant in Pennsylvanian peat swamps that were drier or periodically drier than lycopod-dominated swamps (Phillips et al. 1985). Of all the coals in which Botryococcus is well represented, the Lewisport Coal has the most diverse spore assemblages (Peppers, in press), and lycopod spores are not dominant at all sites. Botryococcus has been observed in more samples of the Delwood Coal than in any other coal, and one of the most distinguishing features of its spore assemblages is the overwhelming abundance of Lycospora (table 2).

\section{PETROGRAPHIC OCCURRENCE OF BOTRYOCOCCUS}

Several coal samples were selected for detailed petrographic study using customary petrographic methods.

Crushed particles representative of the sample were embedded in epoxy and polished to provide statistically representative surfaces for microscopic observations. Vertical illumination microscopy, using an oil immersion lens at 500x magnification, permitted identification of the maceral components that make up the samples. Volumetric percentage of the various components was determined using point counting procedures on the basis of approximately 500 randomly selected counts. Two types of illumination were used: white light from a $100 \mathrm{~W}$ tungsten-quartz-halogen lamp and blue light from a $300 \mathrm{~W}$ mercury arc lamp. The latter used a special optical configuration: a heat filter, a BG12 excitation filter, a dichroic mirror, and a yellow barrier filter-all of which improved the quality of the resultant fluorescence image. This setup significantly improved the ability to identify the alginite and other liptinite macerals in the samples.

Scanning electron microscope (SEM) studies at higher magnifications revealed the ultra-fine structure of the Botryococcus colonies. Millipore filters concentrated representative residues from the macerations left over from the palynological studies. These residues were dried and coated with a gold-palladium conduc- tor under vacuum to enhance the quality of the image in the SEM.

Botryococcus occurs within a matrix of desmocollinite, a low reflecting, moderately dark, gray vitrinite (plate 1, A and B). Botryococcus is also mixed with sporinite in thin beds (plate 1,C and D) and with bituminite in two samples (table 3 ).

Botryococcus-sporinite-rich layers are interbedded with ultra-thin bands of telocollinite, a high-reflecting vitrinite. In addition, scattered inertinite macerals (inertodetrinite, semifusinite, and more rarely fusinite) occur with Botryococcus. Botryococcus represents 0.5 to 3.2 volume percent of the samples studied (table 3 ). Actually, certain layers of the sample contain much greater abundances of Botryococcus than others, for the algae often occur concentrated within ultra-thin beds of the coal, commonly only $200 \mu \mathrm{m}$ thick. There, they composed some $50 \%$ to $75 \%$ of the ultra-thin coal layer. While these samples are not typical of humic coals, they too are predominately composed of the vitrinite group of macerals (table 3 ).

Of particular note is the character of the outer edges of the Botryococcus colonies. These edges appear to retain their cuplike structure (plate 1, F), which is made more evident by the SEM examination of macerated samples (fig. 6). The structure of the cups has long been 
Table 3 Maceral analysis of selected samples as percent volume determined by optical microscopy.

\begin{tabular}{lccccc}
\hline Sample & Vitrinite & Alginite $^{1}$ & Liptinite $^{2}$ & Inertinite & Minerals $^{3}$ \\
\hline Site 8, M2066 & 71.4 & 2.7 & 10.1 & 9.7 & 8.8 \\
Site 41, M2180B & 64.9 & 0.8 & 11.7 & 12.1 & 11.2 \\
Site 41, M2180A & 44.6 & 3.2 & 43.6 & 4.7 & 7.4 \\
Site 43, M2205 & 46.2 & 0.5 & $<15^{5,6}$ & 13.8 & 26.5 \\
\hline
\end{tabular}

1 Alginite is the maceral term for Botryococcus.

${ }^{2}$ Liptinite group includes alginite.

${ }^{3}$ Minerals are primarily clay, fine grained quartz, and framboidal pyrite.

4 Taken from strata that overlie those sampled for M2180A at the same site.

${ }^{5}$ Estimate; bituminite-soaked clays prohibited accurate identification.

6 Bituminite is abundant.

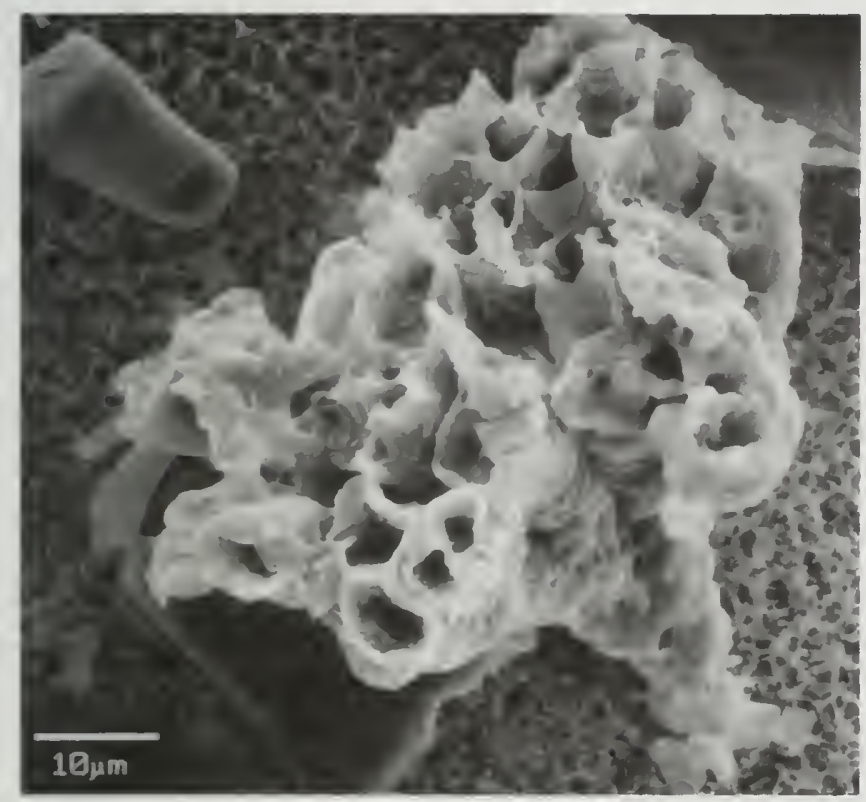

A

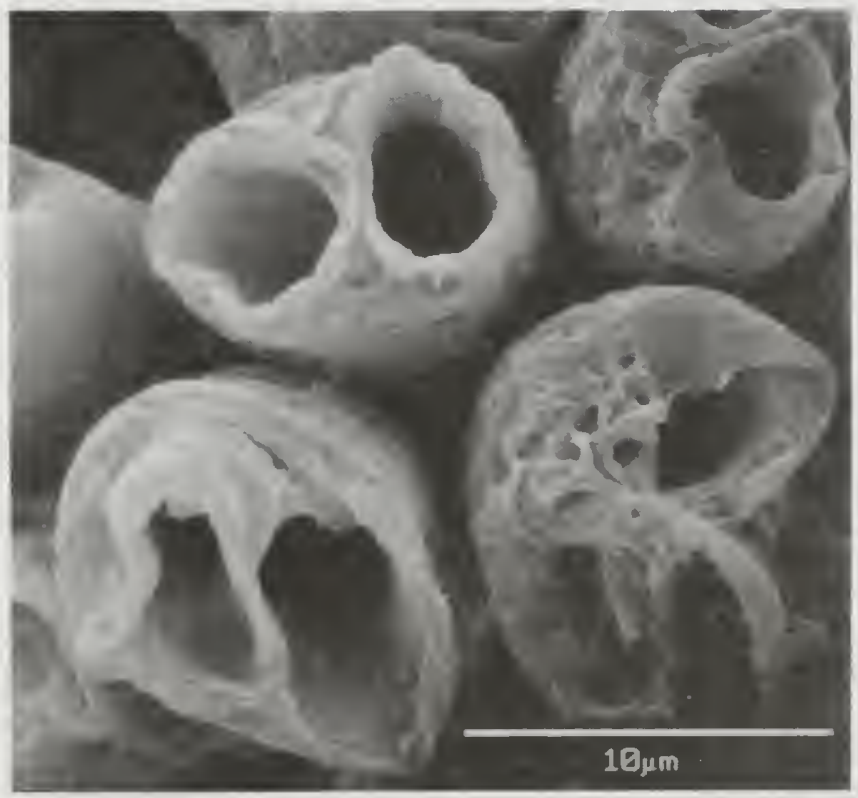

B

Figure 6 SEM micrographs of Botryococcus show the open structure of the cups in the organisms (compare with outer edges shown in Plate 1, F). Macerated specimens rest on millipore filter paper and are shown at magnifications of $1,250 \times(A)$ and $3,700 \times(B)$.

known by microscopic studies of living Botryococcus (Niklas and Phillips 1974). It is not fully understood why these cups have been so well preserved despite being found in bituminous coals whose original organic-rich peats underwent three- to ten-fold compaction during their metamorphism to coal (Kosanke et al. 1958, Stach et al. 1982). While we did not determine the degree of metamorphism (rank) of these samples, they are known to be high-volatile bituminous or higher in rank (Cady 1935). These coals have certainly been bur- ied under hundreds of meters of sediments during their lithification and conversion to coal from late Pennsylvanian to Cretaceous, a period of approximately 160 million years.

The original peat in which Botryococcus colonies were deposited was significantly altered chemically and physically during the coalification that metamorphosed the peat into a suite of macerals that commonly occur in bituminous coal; yet Botryococcus has not been 
coalified, and its morphology has not been significantly altered.

Under the microscope, the polished cross-sectional surfaces of these colonies apparently show many open cups. Along the outer edges of the colonies in the fluorescence images (produced under blue-light illumination; plate 1, F), one can focus into the colonies to a depth of approximately 10 to $20 \mu \mathrm{m}$, which helps confirm the cups (which appear as tubules) are still open.

In the fluorescence images, the darkened, thumbnail-shaped areas along the colony edges indicate partially or wholly open cups. Under the microscope, a flattened cup would not display these shadings.
SEM observation of many Botryococcus colonies appears to show a high abundance of open cups (fig. 6). The cups seen in SEM observations, however, might have been opened by the maceration process used to prepare the specimens. That process, using Schulze's solution (an oxidizing mixture of a saturated solution of $\mathrm{KClO}_{3}$ and $\mathrm{HNO}_{3}$ ) followed by a $5 \%$ solution of $\mathrm{KOH}$, might have caused the once closed or flattened cups to open. The evidence from the fluorescence polished surfaces, however, suggests more conclusively that the cups were not completely closed by the coalification process.

\section{CONCLUSIONS}

Botryococcus, a boghead alga, was observed at a total of 43 sites in the Reynoldsburg, Breckinridge, Bell, St. Meinrad, Mariah Hill, Dunbar, Tarter, Lower Block, Hermon, Brush, Lewisport, Buffaloville, Delwood, Bancroft, and New Burnside Coals and in an unnamed coal in Indiana equivalent to the Murphysboro Coal. Some of these coals are correlative (fig. 3 ). The alga was found most frequently (14 sites) in the Delwood Coal and the Lewisport and Buffaloville Coals (6 sites), which are equivalent. No pattern is apparent in the location or abundance of Botryococcus in various coal beds. The alga ranges from rare to abundant, and spore assemblages are poorly preserved in some macerations in which it is abundant.

Spore analysis of the Lewisport coal and overlying and underlying strata at a site in Union County, Kentucky, indicates that Botryococcus is most abundant in the coal and overlying coaly shale in which Lycospora, produced by Lepidophloios and other lycopod trees, is most abundant (fig. 4). Botryococcus is least abundant in the underclay and overlying gray shale in which Granasporites medius, whose affinity is with Diaphorodendron and Synchysidendron, and fern spores are most abundant. Sphenopsid spores are most abundant where Botryococcus is rare.

Botryococcus is most abundant in other coal beds in which Lycospora is abundant. Since Botryococcus flourished in standing fresh to brackish water, this association is additional evidence that lycopod trees were adapted to very wet environments that were periodically flooded.

The information on the paleoecology of coalswamp floras provided by this study helps interpret the formation and depositional environments of the coals. Since Botryococcus is an indicator of fresh to brackish water (i.e., indicates nonmarine environments), its presence in significant amounts may indicate the location of low-sulfur coal because nonmarine shale commonly directly overlies low-sulfur coal.

In the Illinois Basin, Botryococcus has been observed in coal from the Reynoldsburg Coal Bed to an unnamed coal in Indiana correlative with the Murphysboro Coal Member and ranging in age from the end of the Morrowan to the begining of the Desmoinesian (fig. 3). Although Botryococcus existed from at least as early as the Ordovician to the present, the alga has not been observed in any of the hundreds of macerations of coals above the Murphysboro Coal, including the Springfield (No. 5) and Herrin (No. 6) Coal Members, which extend for thousands of square miles and are major economically important coals. The great abundance of Lycospora in the Herrin and several other coals above the Murphysboro Coal indicates abundant available water in the peat swamps. The absence of Botryococcus above the Murphysboro Coal in the Illinois Basin is presently difficult to explain. Because the alga occurs only between the Murphysboro and Reynoldsburg Coals, its presence can be used in a general way to identify the lower part of the Tradewater Formation in the Illinois Basin.

Botryococcus occurs in coal mostly as irregular colonies and is concentrated in ultra-thin layers, where along with sporinite and minor amounts of other macerals it is embedded in desmocollinite vitrinite. While the associated macerals and lithologic character of the coal beds indicate the coals are bituminous in rank, the Botryococcus colonies were not coalified or significantly changed in form. In fact, microscopic observation suggests that the algal cups have not undergone permanent collapse during the entire period of coalification. 


\section{REFERENCES}

Allan, J., M. Bjoroy, and A.G. Douglas, 1980, A geochemical study of the exinite group maceral alginite, selected from three Permo-Carboniferous torbanites, in A.G. Douglas and J.R. Maxwell, editors, Advances in Organic Geochemistry, Ninth International Meeting on Organic Geochemistry, Newcastle-uponTyne, U.K., 1979: Pergamon, Oxford, p. 599-618.

Bain, H.F., 1906, Zinc and Lead Deposits of the Upper Mississippi Valley: U.S. Geological Survey, Bulletin $294,155 \mathrm{p}$.

Barrett, N.O., 1922, Notes on Illinois bituminous shales, including results of their experimental distillation: Illinois State Geological Survey Bulletin 38, p. 441-460.

Bertrand, C.E., and B. Renault, 1892, Pila bibractensis et le boghead d'Autun: Société d'Histoire Naturelle d'Autun Bulletin 5, p. 159-253.

Bertrand, C.E., and B. Renault, 1893, Reinschia australis et premières remarques sur la kerosene shale de la Nouvelle-Galles du Sud: Société d'Histoire Naturelle d'Autun Bulletin 6, p. 321-425.

Blackburn, K.B., and B.N. Temperley, 1936, Botryococcus and the algal coals: Transactions of the Royal Society of Edinburgh, v. 58, p. 841-868.

Bradley, W.H., 1966, Tropical lakes, copropel, and oil shale: Geological Society of America Bulletin 77, p. 1333-1338.

Cady, G.H., 1935, Classification and Selection of Illinois Coals: Illinois State Geological Survey Bulletin 62, $354 \mathrm{p}$.

Cooper, C.L., 1946, Pennsylvanian Ostracodes of Illinois: Illinois State Geological Survey Bulletin 70, $177 \mathrm{p}$.

DiMichele, W.A., and T.L. Phillips, 1985, Arborescent lycopod reproduction and paleoecology in a coalswamp environment of late Middle Pennsylvanian age (Herrin Coal, Illinois, U.S.A.): Review of Palaeobotany and Palynology, v. 44, p. 1-26.

DiMichele, W.A., T.L. Phillips, and R.A. Peppers, 1985, The influence of climate and depositional environment on the distribution and evolution of Pennsylvanian coal-swamp plants, in B.H. Tiffney, editor, Geological Factors and the Evolution of Plants: Yale University Press, New Haven, p. 223-256.

Dulhunty, J.A., 1944, Origin of the New South Wales torbanites: Linnean Society of New South Wales, Proceedings, v. 49 , p. 26-48.

Guennel, G.K., 1958, Miospore Analysis of the Pottsville Coals of Indiana: Indiana Geological Survey, Bulletin $13,101 \mathrm{p}$.

Greb, S.F., D.A. Williams, and A.D. Williamson, 1992, Geology and Stratigraphy of the Western Kentucky Coal Field: Kentucky Geological Survey, Bulletin 2, Series XI, $77 \mathrm{p}$.

Hower, J.C., D.N. Taulbee, C. Poole, and D.W. Kuehn, 1986, Petrology and geochemistry of the Breckinridge seam-A torbanite from western Kentucky: Proceedings, 1986 Eastern Oil Shale Symposium, p. 267-280.
Hutchison, H.C., 1959, Distribution, structure, and mined areas of coals in Spencer County, Indiana: Indiana Geological Survey, Preliminary Coal Map No. 8.

Hutchison, H.C., 1971, Distribution, structure, and mined areas of coals in Daviess County, Indiana: Indiana Geological Survey, Preliminary Coal Map No. 15.

Jeffrey, E.C., 1910, The nature of some supposed algal coals: American Academy of Arts and Sciences, Procedings v. 96, p. 273-290.

Kosanke, R.M., 1950, Pennsylvanian Spores of Illinois and Their Use in Correlation: Illinois Geological Survey Bulletin 74, 128 p.

Kosanke, R.M., 1951, A type of boghead coal from Illinois: American Journal of Science, v. 249, no. 6 , p. $444-450$.

Kosanke, R.M., J.A. Simon, and W.H. Smith, 1958, Compaction of plant debris-forming coal beds: Geological Society of America, Abstracts, Bulletin 69, p. 1599-1600.

Moore, L.R., 1968, Cannel coals, bogheads and oil shales, in D.G. Murchison and T.S. Westoll, editors, Coal and Coal-bearing Strata: Oliver and Boyd, Edinburgh, p. 19-29.

Nelson, W.J., and D.K. Lumm, 1990, Geologic Map of the Eddyville Quadrangle, Illinois: Illinois State Geological Survey, Illinois Geological Quadrangle Map 5.

Niklas, K.J., 1976, Chemical examinations of some nonvascular Paleozoic plants: Brittonia, v. 28, p. 113-137.

Niklas, K.J., and T.L. Phillips, 1974, Morphological and microchemical correlations of living and fossil Botryococcus: Geological Society of America, Abstracts with Programs, v. 6, no. 7, p. 891.

Peppers, R.A., 1996, Palynological Correlation of Major Pennsylvanian (Middle and Upper Carboniferous) Chronostratigraphic Boundaries in the Illinois and Other Coal Basins: Geological Society of America, Memoir 188, $111 \mathrm{p}$.

Peppers, R.A., in press, Paiynological Correlation of the Lewisport Coal Bed (Early Desmoinesian) and Equivalent Coals in the Illinois Basin: Illinois Basin Studies.

Phillips, T.L., 1980, Stratigraphic and geographic occurrences of permineralized coal-swamp plants-Upper Carboniferous of North America and Europe, in D.L. Dilcher and T.N. Taylor, editors, Biostratigraphy of Fossil Plants: Dowden, Hutchinson, and Ross, Inc., Stroudsburg, PA, p. 25-92.

Phillips, T.L., and R.A. Peppers, 1984, Changing patterns of Pennsylvanian coal-swamp vegetation and implications of climatic control on coal occurrence: International Journal of Coal Geology, v. 3, p. 205-255.

Phillips, T.L., R.A. Peppers, and W.A. DiMichele, 1985, Stratigraphic and interregional changes in Pennsylvanian coal-swamp vegetation-Environmental inferences, in T.L. Phillips and C.B. Cecil, editors, 
Paleoclimatic Control on Coal Resources of the Pennsylvanian System of North America: International Journal of Coal Geology, v. 5. p. 43-109.

Renault, B., 1899-1900, Sur quelques microorganisms des combustibles fossils: Société de l'industrie minérale de St. Etienne Bulletin, Third Series, v. 13, p. 865-1161; v. 14, p. 5-159.

Schopf, J.M., 1949, Cannel, boghead, torbanite, oil shale: Economic Geology, v. 44, p. 68-71.

Schopf, J.M., 1952, Comments on papers, Second Conference on the Origin and Constitution of Coal, Crystal Cliffs, Nova Scotia: Nova Scotia Department of Mines and Nova Scotia Research Foundation, p. 111, 317-318, 338.

Shaver, R.H., and S.G. Smith, 1974, Some Pennsylvanian Kirkbiacean Ostracods of Indiana and Midcontinent Series Terminology: Indiana Geological Survey Report of Progress 31, $69 \mathrm{p}$.

Smith, A.H.V., 1957, The sequence of microspore assemblages associated with the occurrence of crassidurite in coal seams of Yorkshire: Geology Magazine, v. 94, p. 345-363.

Smith, A.H.V., and M.A. Butterworth, 1967, Miospores in the Coal Seams of the Carboniferous of Great Britain: Special paper in Palaeontology, no. 1, Palaeontology Association, London, 324 p.

Smith, G.M., 1950, Fresh-water Algae of the United States, 2nd edition: McGraw Hill, New York, p. 404-405.
Smith, W.H., 1957, Strippable Coal Reserves of Illinois, Pt. 1 - Gallatin, Hardin, Johnson, Pope, Saline, and Williamson Counties: Illinois State Geological Survey Circular 228, $39 \mathrm{p}$.

Stach, E., G.H. Taylor, M. T. Mackowsky, D. Chandra, M. Teichmüller, and R. Teichmüller, 1982, Coal Petrology: Gebrüder Borntraeger, Berlin, Stuttgart, p. 17-18.

Thiessen, R., 1925, Origin of the boghead coals: U.S. Geological Survey, Professional Paper 132-I, p. 121-138.

Trask, C.B. and R.J. Jacobson, 1990, Geologic Map of the Creal Springs Quadrangle: Illinois State Geological Survey, Illinois Geologic Quadrangle 4, 1:24,000 scale.

Williams, D.A., A.D. Williamson, and J.G. Beard, 1982, Stratigraphic Framework of Coal-bearing Rocks in the Western Kentucky Coal Field: Kentucky Geological Survey, Series XI, Information Circular 8, $201 \mathrm{p}$.

Zalessky, M.D., 1914, On the nature of Pila of the yellow bodies of boghead and on sapropel of the Ala-Kool Gulf of the Lake Balkash: Bulletin du Comité Géologique de Russie, Petrograd, Bulletin, v. 33, p. 495-507.

Zalessky, M.D., 1926, Sur les nouvelles algues déscouvertes dans le sapropélogène du Lac Beloe (Hauteurs de Valdai) et sur une algue sapropélogène, Botryococcus braunii Kützing: Revue Général de Botanique, v. 38 , p. $30-42$. 


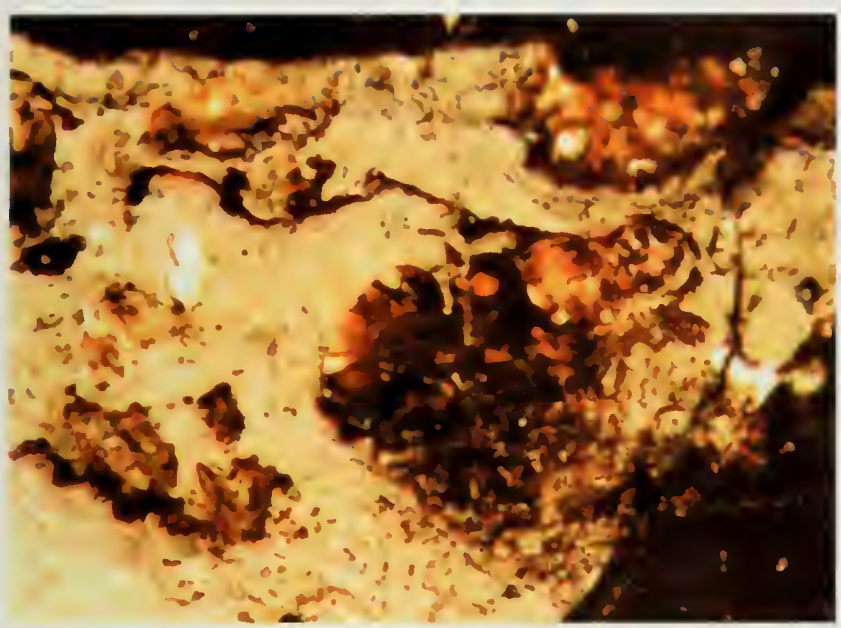

A

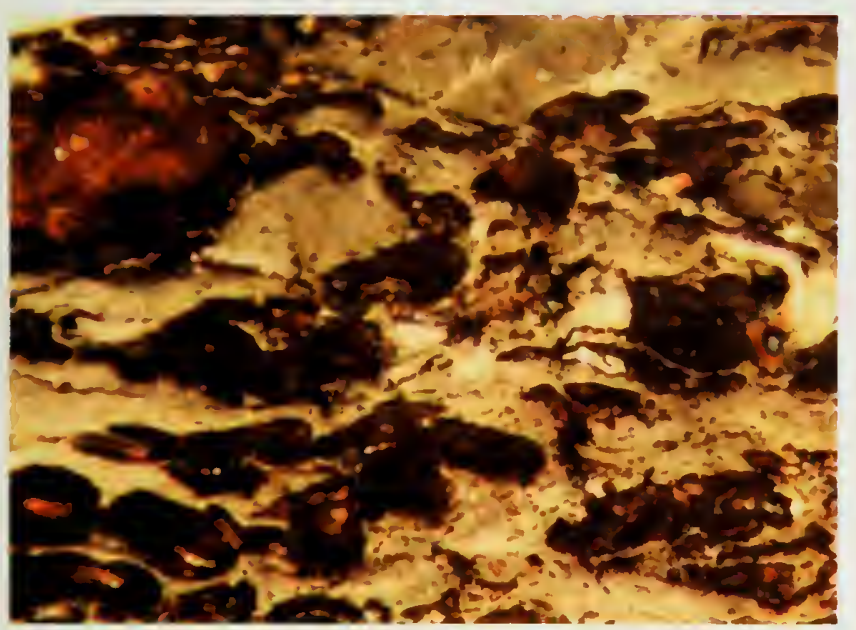

C

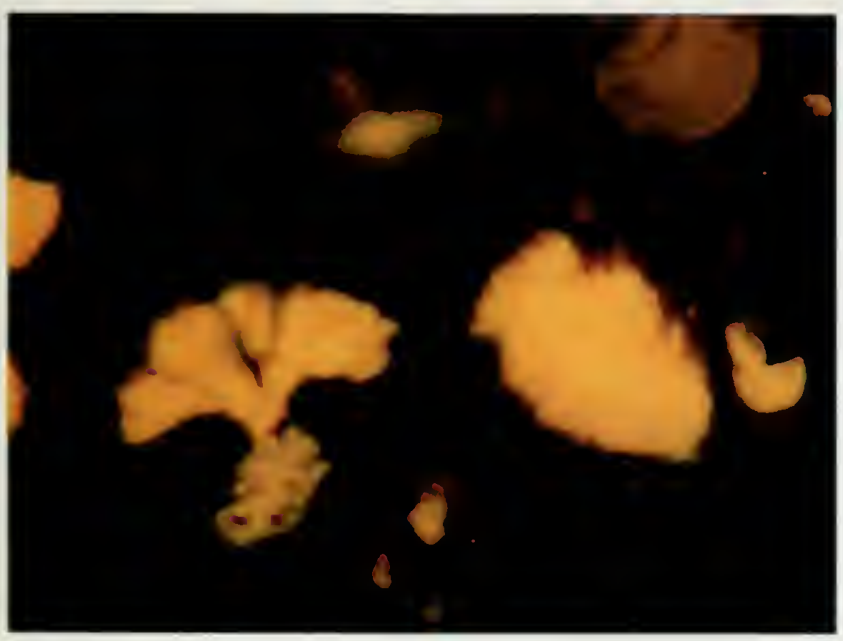

E

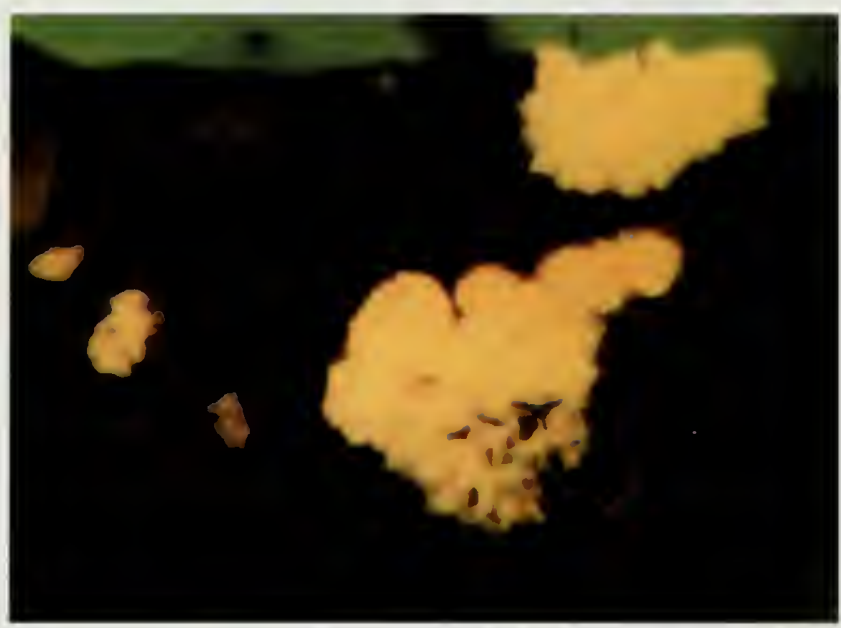

B

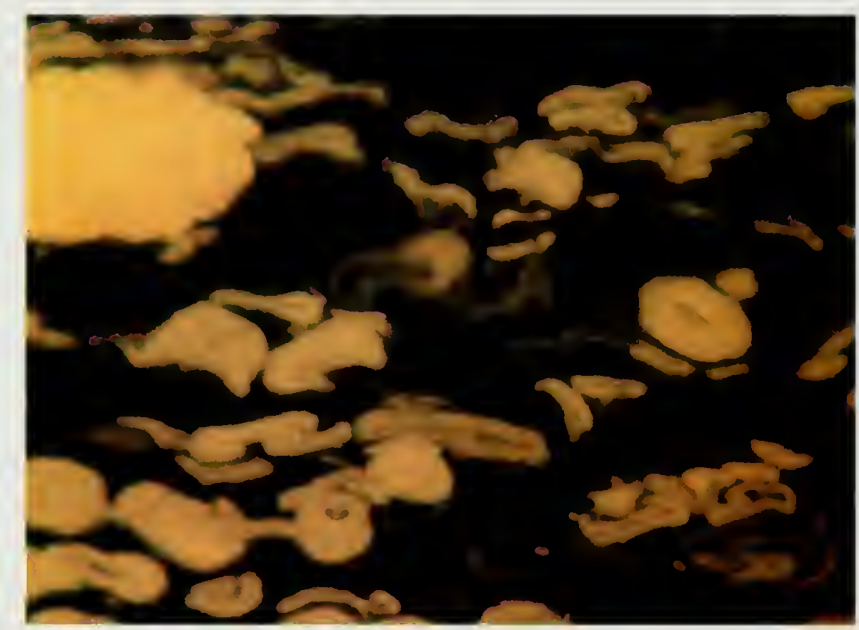

D

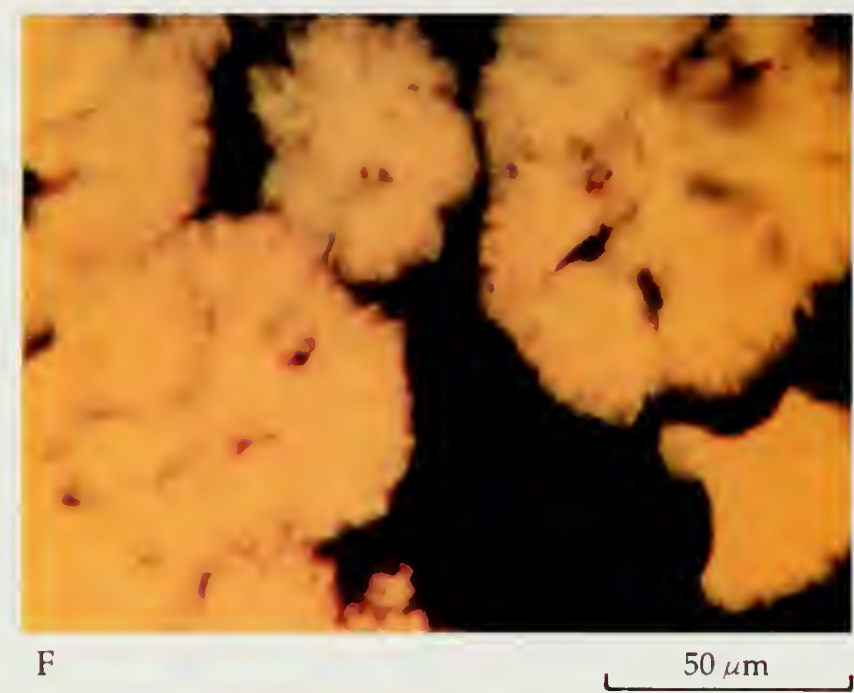

Plate 1 The occurrence of Botryococcus in crushed particles of coal. Samples were embedded in epoxy, polished, and examined under an oil immersion lens. All images are magnified about 400x. Pairs A and B and C and D are the same image. Under white light (A and C), Botryococcus appears mottled reddish brown, whereas under blue light excitation (B, D, E, and F) it fluoresces bright yellow. Liptinite macerals associated with Botryococcus include sporinite (dark brown in C and dull yellow in D) and small irregular masses of bituminite (brown in A and faintly brown in B and E). The matrix commonly surrounding Botryococcus is desmocollinite (gray in A and C), a type of vitrinite. In F, the outer edges of the alga masses appear scalloped. 


